\title{
Genomic convergence and network analysis approach to identify candidate genes in Alzheimer's disease
}

\author{
Puneet Talwar' ${ }^{1}$ Y Yumnam Silla', Sandeep Grover ${ }^{1}$, Meenal Gupta', Rachna Agarwal' , Suman Kushwaha ${ }^{3}$
} and Ritushree Kukreti ${ }^{*}$

\begin{abstract}
Background: Alzheimer's disease (AD) is one of the leading genetically complex and heterogeneous disorder that is influenced by both genetic and environmental factors. The underlying risk factors remain largely unclear for this heterogeneous disorder. In recent years, high throughput methodologies, such as genome-wide linkage analysis (GWL), genome-wide association (GWA) studies, and genome-wide expression profiling (GWE), have led to the identification of several candidate genes associated with AD. However, due to lack of consistency within their findings, an integrative approach is warranted. Here, we have designed a rank based gene prioritization approach involving convergent analysis of multi-dimensional data and protein-protein interaction (PPI) network modelling.

Results: Our approach employs integration of three different AD datasets- GWL,GWA and GWE to identify overlapping candidate genes ranked using a novel cumulative rank score $\left(S_{R}\right)$ based method followed by prioritization using clusters derived from PPI network. $S_{R}$ for each gene is calculated by addition of rank assigned to individual gene based on either $p$ value or score in three datasets. This analysis yielded 108 plausible AD genes. Network modelling by creating PPI using proteins encoded by these genes and their direct interactors resulted in a layered network of 640 proteins. Clustering of these proteins further helped us in identifying 6 significant clusters with 7 proteins (EGFR, ACTB, CDC2, IRAK1, APOE, ABCA1 and AMPH) forming the central hub nodes. Functional annotation of 108 genes revealed their role in several biological activities such as neurogenesis, regulation of MAP kinase activity, response to calcium ion, endocytosis paralleling the AD specific attributes. Finally, 3 potential biochemical biomarkers were found from the overlap of 108 AD proteins with proteins from CSF and plasma proteome. EGFR and ACTB were found to be the two most significant $A D$ risk genes.
\end{abstract}

Conclusions: With the assumption that common genetic signals obtained from different methodological platforms might serve as robust AD risk markers than candidates identified using single dimension approach, here we demonstrated an integrated genomic convergence approach for disease candidate gene prioritization from heterogeneous data sources linked to AD.

Keywords: Gene prioritization, Protein-protein interaction, Clustering, Functional annotation

\footnotetext{
* Correspondence: ritus@igib.res.in

${ }^{1}$ Genomics and Molecular Medicine Unit, Institute of Genomics and Integrative Biology (IGIB), Council of Scientific and Industrial Research (CSIR), Mall Road, Delhi 110 007, India

Full list of author information is available at the end of the article
} 


\section{Background}

Alzheimer's disease (AD) is a gradually progressive neurodegenerative disease, characterized by cognitive impairment in elderly. Genetics is known to play a major role in its development with studies showing both gene-gene and geneenvironment interactions as risk factors [1,2]. The number of people afflicted with $\mathrm{AD}$ is estimated to be more than 24 million worldwide, and the heritability is estimated to be $60-80 \%$ [3-5]. Over the last decade, several high throughput experimental approaches involving genome-wide linkage (GWL) scans, genome-wide association (GWA) studies, and genome-wide expression (GWE) profiling, have been extensively utilized to identify the underlying genetic risk factors. Linkage studies were instrumental in the initial identification of four genes (APP, PSEN1, PSEN2 and $A P O E$ ) associated with $\mathrm{AD}$ [6]. Later, several other loci spanning many genes were discovered in AD using GWL scans. However, linkage studies in sporadic or late onset AD (LOAD) suffers from limitations of low resolution of results, lack of availability of large multigeneration families and inclusion of phenocopies [7].

With the advent of high throughput genotyping platforms in recent years, several GWA studies were carried out using population based case-control designs which resulted in the identification of additional AD risk genes $[7,8]$. However, these studies require very large sample size specifically to detect genetic variant with small attributable risk. Additionally, case control studies are prone to issues of population stratification and population admixture. In recent years, a limited number of global gene expression profiling studies have been conducted using post-mortem AD brain tissues $[9,10]$. These studies have led to identification of genes related to multiple cellular pathways known to be involved in AD pathogenesis and progression. However, the major drawback of such studies includes limited access to brain samples from AD subjects as well as age matched controls. Further, variable RNA quality due to post-mortem delay and the difficulty in establishing temporal and regional specificity of gene expression changes adds up to the limitations [11]. Although different genetic based approaches have led to the accumulation of massive amounts of data, however, due to differential limitations of each study, limited success has been achieved in identifying common underlying genetic markers related to AD progression and pathogenesis. This warrants designing of novel approaches complementing the existing ones for disease gene discovery.

In recent years, integrative approaches combining multiple data sources have been widely used to identify susceptible genes in complex disorders such as AD [12,13], epilepsy [14], type 2 diabetes [15,16], prostate cancer [17], depression [18], schizophrenia [19] and Parkinson's disease (PD) [20]. Such approaches may help imbibe disease specific biological knowledge that may not be available from one dimensional approaches. Further, network modelling of gene-gene and protein-protein interactions (PPI) provides a relatively new integrative approach to understand complex disease and identify disease-related genes $[21,22]$. For instance, candidate genes in complex disorders, such as AD [23-27], obstructive sleep apnea [28], heart failure [29], cancer [30] and cardiorenal syndrome [31], have already been explored extensively using PPI based approach. Thus, a convergent analysis approach involving multi-dimensional datasets combined with network or pathway analysis might serve as a comprehensive approach for disease candidate gene prioritization.

In this study, we aimed to develop a system biology approach based on genomic convergence of genetic data from multiple high-dimensional genome-wide studies and network modelling of protein-protein interactions to prioritize candidate genes linked to $\mathrm{AD}$. We identified 108 common overlapping genes from integrated analysis of three datasets - GWL [8,32,33], GWA [34] and GWE [[35,36]; GSE5281] and ranked them using our ranked based scoring method. We identified direct protein interactors of 108 candidate genes and then created a layered PPI network comprising of 640 nodes based on subcellular localization of proteins. Finally, we performed Markov Cluster algorithm (MCL) based clustering using clusterMaker and functional enrichment analysis using the Database for Annotation, Visualization and Integrated Discovery (DAVID) to identify functional modules and significant Gene Ontology (GO) annotation clusters, respectively [37-39]. Hence, integrating AD linkage, genetic association, and gene expression data followed by network modelling of PPI resulted in a list of evidence-based candidate genes for future experimental validation and related pathways for better understanding of underlying $\mathrm{AD}$ patho-physiology. This multi-dimensional evidence-based approach can be applied to other complex disorders having publically available high throughput data.

\section{Results}

The objective of this study was to identify potential candidate genes involved in $\mathrm{AD}$ development and progression by an integrative genomic convergence approach involving rank based scoring method. The datasets, for integrative analysis, were retrieved from AlzGene database (GWL), I-GAP (International Genomics of Alzheimer's Project) study (GWA) and NCBI Gene Expression Omnibus (GEO) database: GSE5281 (GWE). The common overlapping genes occurring in all the three datasets were identified and ranked by cumulative rank score obtained by addition of gene ranks based on either $\mathrm{p}$ values or scores. The final 108 overlapping genes were used for 'GO analysis' and to create a layered PPI network comprising 640 nodes and 2214 edges. These identified putative proteins were then used to identify functionally important clusters and 
common biomarkers among plasma/serum and CSF proteome. The entire work flow is depicted in Figure 1.

Putative AD linked candidate genes from integrative analysis For GWL data analysis, genomic linkage regions linked to $\mathrm{AD}$ were retrieved from AlzGene database with LOD scores $\geq 2.0$ or $\mathrm{p}$ value $<0.05$ (1p31.1-q31.1, 3q12.3-q25.31, 6p21.1-q15, 7pter-q21.11, 8p22-p21.1, 9q21.31-q32, 10p14q24, 17q24.3-qter, 19p13.3-qter) and used for further analysis. Among these 9 linkage regions, 7 were included from meta-analysis of five independent genome scans carried out by Butler et al. [32], using genome search meta-analysis (GSMA) approach and 2 regions from Hamshree et al. [33] that combined three large samples to give a total of 723 affected relative pairs (ARPs) and analyzed using multipoint, model-free ARP linkage analysis approach. A total of 2976 genes were retrieved using UCSC genome browser [40] from these linkage regions and genes were ranked according to their score obtained from GeneWanderer web server [41].
Further, for the GWA dataset, 19,532 single nucleotide polymorphisms (SNPs) with p value $<0.0001$ [34] were selected. These SNPs were mapped to their corresponding genes using NCBI Variation Reporter, SCAN (SNP and CNV Annotation) database [42] and SPOT web tool [43]. This led us to the identification of 1,686 genes which were ranked based on weighted $\mathrm{p}$ value obtained though genomic information network prioritization and scoring method implemented in SPOT [43]. For replication analysis, we used another GWA dataset from Boada et al. [44] which included genotyped and imputed SNPs $(1,098,485)$ from 7 reported GWA studies comprising $\sim 8082$ cases and $\sim 12040$ controls for stage I meta-analysis. With this cohort used in stage I analysis with $\mathrm{P}<0.001,1202$ SNPs were obtained. When candidate genes identified in the main and replication datasets were compared, we found a concordance of 35.4\% (see Additional file 1).

For GWE data analysis, the GSE5281 dataset was selected and analyzed using GEO2R tool accessed from GEO web server [45]. In our study, expression data from

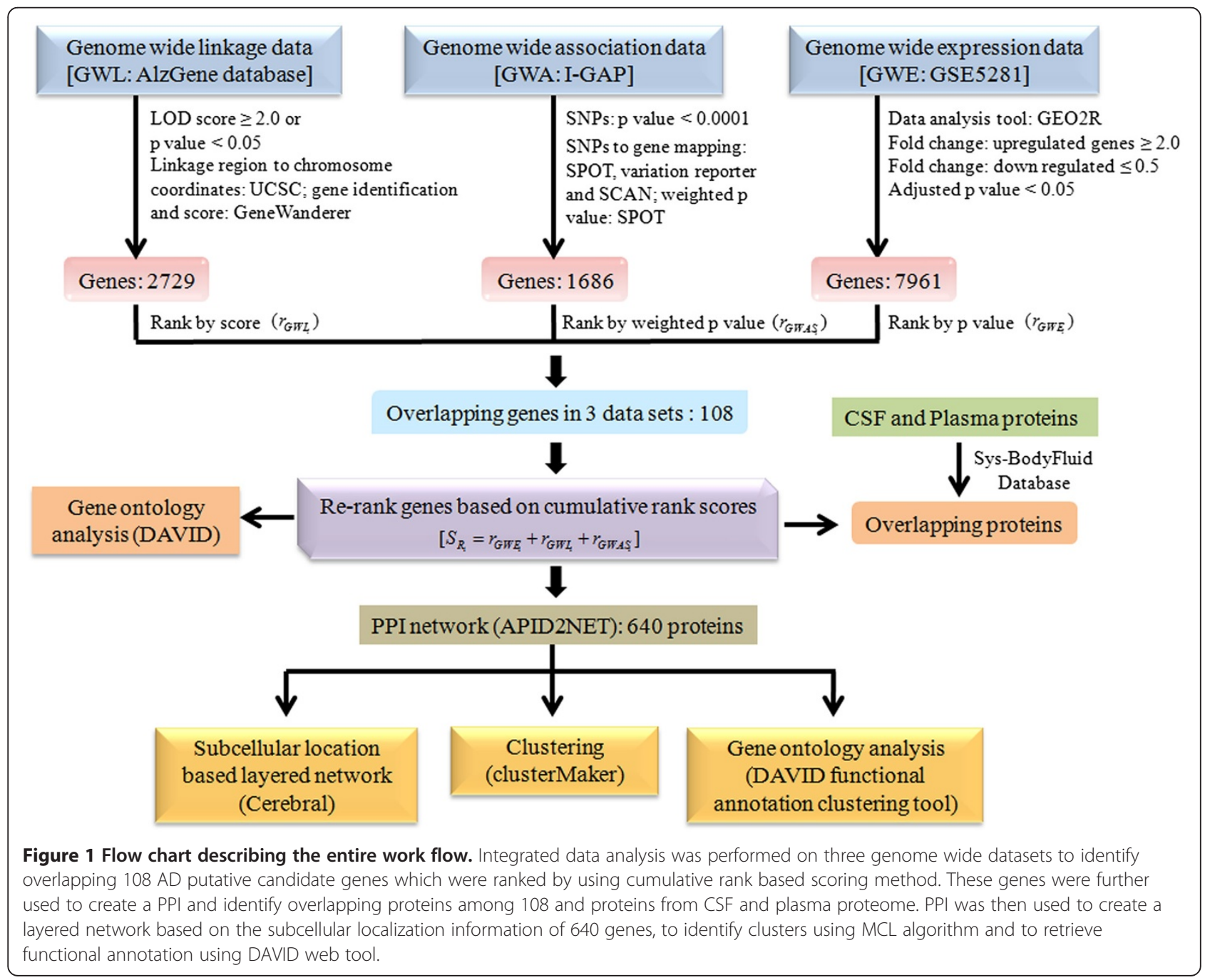


six brain regions - entorhinal cortex (EC), hippocampus (HIP), posterior cingulate cortex (PC), middle temporal gyrus (MTG), superior frontal gyrus (SFG) and primary visual cortex (VCX), were used for analysis. The genes with adjusted $\mathrm{p}$ value $<0.05$ and fold change $\geq 2.0$ for upregulated genes and $\leq 0.5$ for down regulated genes were selected from each region and then merged. This analysis resulted in 7961 genes which were ranked by their corresponding adjusted $\mathrm{p}$ values. For replication analysis, we used another GWE dataset - GSE15222 that comprised expression data from post-mortem brain cortical regions of 176 late-onset $\mathrm{AD}$ cases and 188 controls [46]. A concordance of $58.2 \%$ was found between GSE5281 and GSE15222 datasets after analysis (see Additional file 1).

The intersection of all the three datasets resulted in the final set of 108 putative candidate genes (Figure 2) and their individual ranks were added to get $S_{R_{i}}$ score. Based on this rank score the genes were re-ranked with gene having the lower cumulative rank score getting the higher rank. The top 10 genes are listed in Table 1 and the list of 108 genes is provided in Additional file 2.

As all the six brain regions are found to be associated with $\mathrm{AD}$ pathology with different degree of involvement depending upon disease severity, we analysed expression profile data of each region separately and obtained candidate

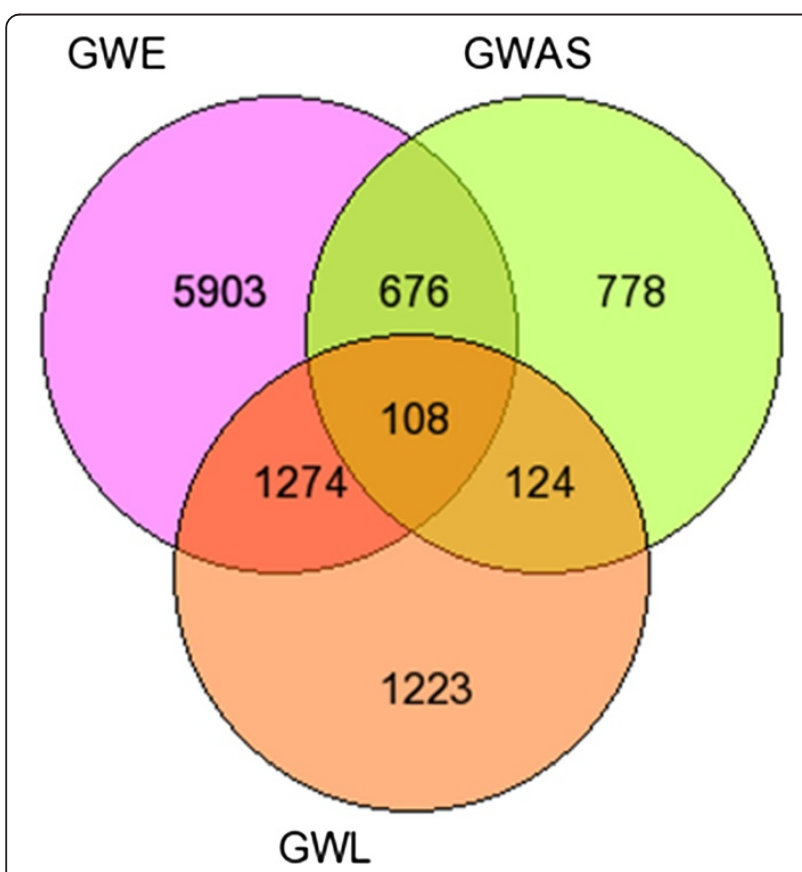

Figure 2 Venn diagram of putative overlapping AD candidate genes among different genome wide datasets. The venn diagram represents the genes in the three individual datasets and overlapping 108 putative AD target genes identified by integrated analysis of the three datasets. genes specific in each brain region. We identified 25,16 , 40, 38, 27 and 1 candidate genes specific in EC, HIP, PC, MTG, SFG and VCX brain regions, respectively, from overlap with GWA and GWL repertoires (see Additional files 3 and 4).

\section{Protein-protein interaction network, layering and network analysis}

Identification of proteins that interact directly with proteins encoded by identified 108 target genes might help elucidate the molecular mechanism underlying $\mathrm{AD}$ patho-physiology. Thus, in the present study, we created a PPI network from the 108 candidate genes using APID2NET plugin in Cytoscape [47,48] comprising 640 nodes and 2214 edges. Then, a layered network based on the sub-cellular localization information of 640 proteins using "Cerebral" plugin [49] in Cytoscape was obtained from the PPI network. The layered network is depicted in Figure 3. Further, another cytoscape plugin "clusterMaker" [37] was used on the PPI to create clusters using MCL clustering algorithm [50]. This resulted in the identification of 6 important clusters with 7 proteins (EGFR, ACTB, CDC2, IRAK1, APOE, ABCA1 and $\mathrm{AMPH}$ ) forming the central hub nodes (Figure 4a-f). All 63 clusters obtained from MCL clustering are provided in Additional file 5.

\section{Functional annotation analysis by $\mathrm{GO}$ terms}

We performed functional GO enrichment analysis of the 108 AD candidate genes, using functional annotation clustering tool implemented in DAVID [38,39], to identify association of candidate genes with different 'GO terms'. The significantly over represented 'GO terms', identified neurogenesis $(p=0.0032)$ as the top cluster, followed by regulation of neurogenesis $(p=0.0062)$. The other significantly over represented biological processes included peptidyl tyrosine phosphorylation $(\mathrm{p}=0.0041)$, cytoplasmic membrane-bounded vesicles $(\mathrm{p}=0.006)$, regulation of MAP kinase activity $(\mathrm{p}=0.0005)$, kinase activity $(\mathrm{p}=$ 0.0081), purinergic nucleotide receptor activity, G-protein coupled $(p=0.0153)$, neuron development $(p=0.0098)$, response to calcium ion $(\mathrm{p}=0.0067)$, sensory perception of light stimulus $(p=0.0041)$, endocytosis $(p=0.0192)$ (Figure 5). This analysis was also repeated for 640 candidate genes (Additional file 6).

\section{AD putative biochemical biomarkers}

In this study, we also looked for the identification of cerebrospinal fluid (CSF) and plasma based AD specific biomarker and found 3 common proteins (APOE, EGFR, $\mathrm{ACTB}$ ) among $108 \mathrm{AD}$ proteins and proteins from CSF and plasma proteome (Figure 6) and 38 common proteins among 640 putative $\mathrm{AD}$ proteins and proteins from CSF and plasma proteome (Additional file 7), which 
Table 1 Top 10 genes from the list of 108 target genes found in the overlap of three data sets

\begin{tabular}{|c|c|c|c|c|c|c|c|c|c|}
\hline $\begin{array}{l}\text { S. } \\
\text { No. }\end{array}$ & $\begin{array}{l}\text { Gene } \\
\text { Symbol }\end{array}$ & Gene Name & $\begin{array}{l}\text { Rank } \\
\text { GWL }\end{array}$ & $\begin{array}{l}\text { Rank } \\
\text { GWA }\end{array}$ & $\begin{array}{l}\text { Rank } \\
\text { GWE }\end{array}$ & $\begin{array}{l}\text { Cumulative } \\
\text { rank score }\end{array}$ & $\begin{array}{l}\text { Final } \\
\text { rank }\end{array}$ & HGNC ID & Location \\
\hline 1 & RPN1 & Ribophorin I & 232 & 61 & 324 & 617 & 1 & HGNC:10381 & $3 q 21.3$ \\
\hline 2 & RGS4 & Regulator of G-protein signaling 4 & 240 & 300 & 97 & 637 & 2 & HGNC:10000 & $1 \mathrm{q} 23.3$ \\
\hline 3 & HIP1 & Huntingtin interacting protein 1 & 548 & 29 & 303 & 880 & 3 & HGNC:4913 & $7 q 11.23$ \\
\hline 4 & PTK2B & Protein tyrosine kinase 2 beta & 148 & 14 & 879 & 1041 & 4 & HGNC:9612 & $8 p 21.1$ \\
\hline 5 & $\mid C A 1$ & Islet cell autoantigen 1, $69 \mathrm{kDa}$ & 323 & 453 & 268 & 1044 & 5 & HGNC:5343 & $7 p 22$ \\
\hline 6 & $\mathrm{AMPH}$ & Amphiphysin & 540 & 539 & 194 & 1273 & 6 & HGNC:471 & 7p14-p13 \\
\hline 7 & ATP5H & $\begin{array}{l}\text { ATP synthase, } \mathrm{H}+\text { transporting, mitochondrial } \\
\text { Fo complex, subunit } d\end{array}$ & 817 & 279 & 192 & 1288 & 7 & HGNC:845 & $17 q 25$ \\
\hline 8 & EGFR & Epidermal growth factor receptor & 24 & 434 & 909 & 1367 & 8 & HGNC:3236 & $7 p 12$ \\
\hline 9 & $A B C A 1$ & $\begin{array}{l}\text { ATP-binding cassette, sub-family A (ABC1), } \\
\text { member } 1\end{array}$ & 47 & 217 & 1138 & 1402 & 9 & HGNC:29 & $9 q 31$ \\
\hline 10 & $A C T B$ & Actin, beta & 49 & 1348 & 10 & 1407 & 10 & HGNC:132 & $7 p 22$ \\
\hline
\end{tabular}

might serve as potential biochemical biomarkers for early detection of AD cases in future.

\section{Validation of Rank based approach by using PD datasets} For validation of our rank based gene prioritization approach, we selected $\mathrm{PD}$, another common complex neurodegenerative disorder that involves the deposition of $\alpha$-synuclein as intracellular Lewy bodies leading to progressive degeneration of dopaminergic neurons within multiple brain regions. It clinically manifests as both a movement disorder, characterized by tremor, rigidity, bradykinesia and postural instability and a distinct form of cognitive impairment, characterized by visuospatial impairment and fluctuations in mental state [51,52]. We applied our rank based method to identify overlapping genes in three PD datasets - GWL, GWA, and GWE. We

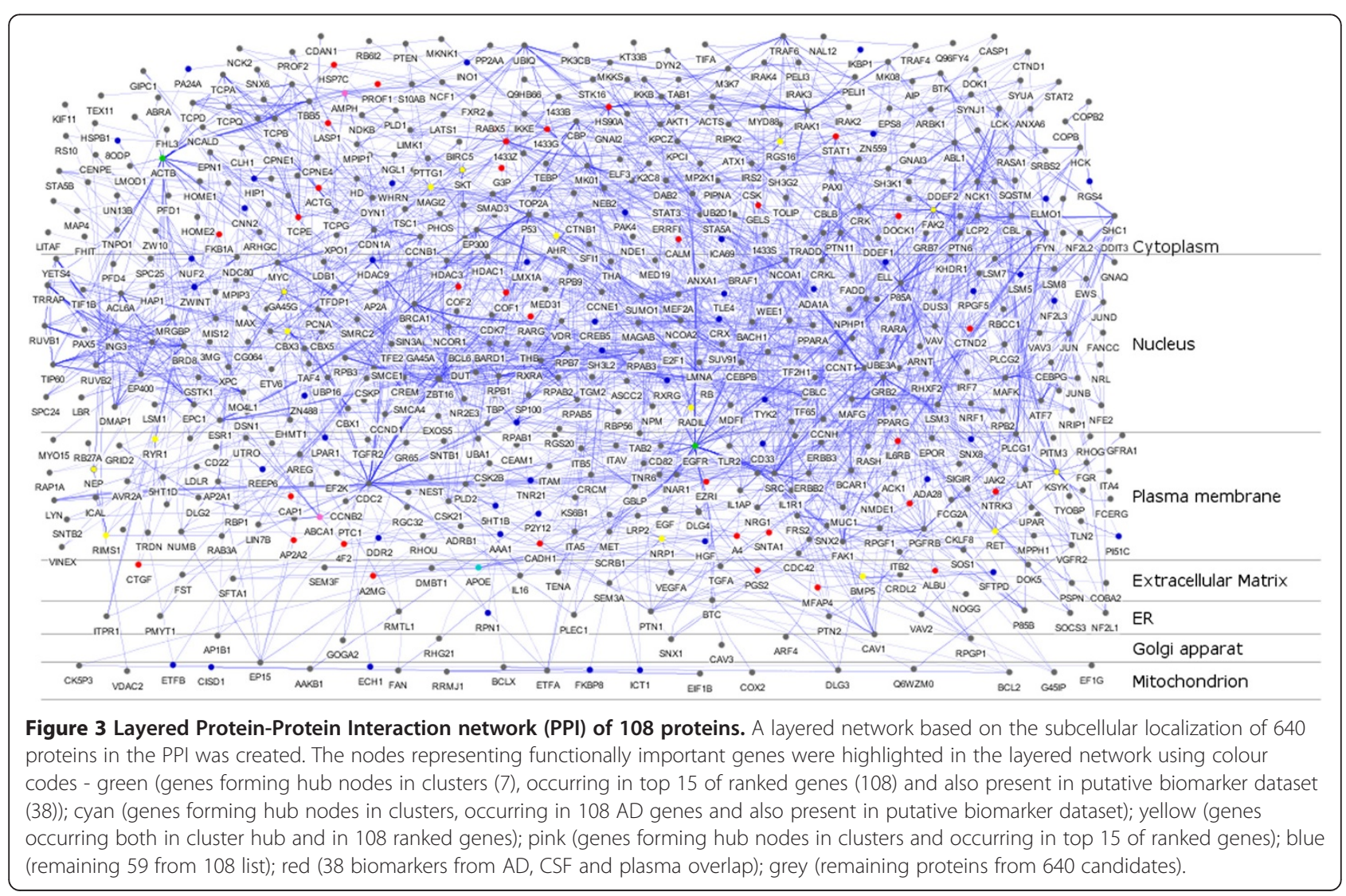




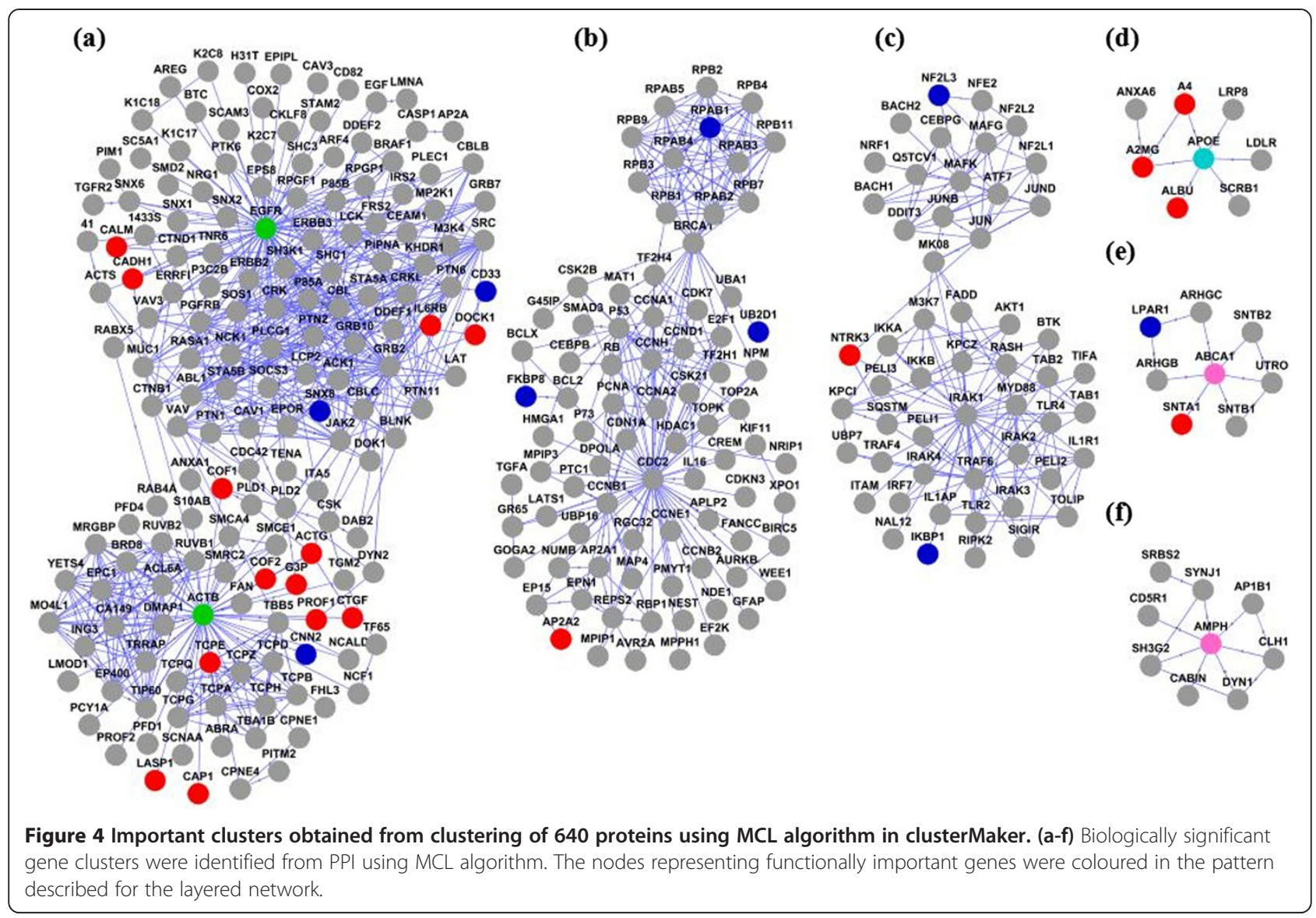

retrieved GWL dataset from PDgene database (http:// www.pdgene.org/) [53]. It included genetic loci showing evidence for linkage in the meta-analysis of five GWL scans comprising 862 families with 1384 affected subjects using the GSMA method by Rosenberger et al. [54].

For GWA dataset, we retrieved SNPs with pre-computed $p$ values from a NCBI dbGaP database with study accession: phs000089.v3.p2 (http://www.ncbi.nlm.nih.gov/gap)
[55]. This dataset comprises PD cases drawn from population of North American Caucasians, and neurologically normal controls from the population which are banked in the National Institute of Neurological Disorders and Stroke (NINDS Repository) collection for a stage I genome wide analysis. Initially, genome-wide, SNP genotyping of these samples was carried out in 267 PD subjects and 270 controls, and later extended to include genotyping in 939 PD

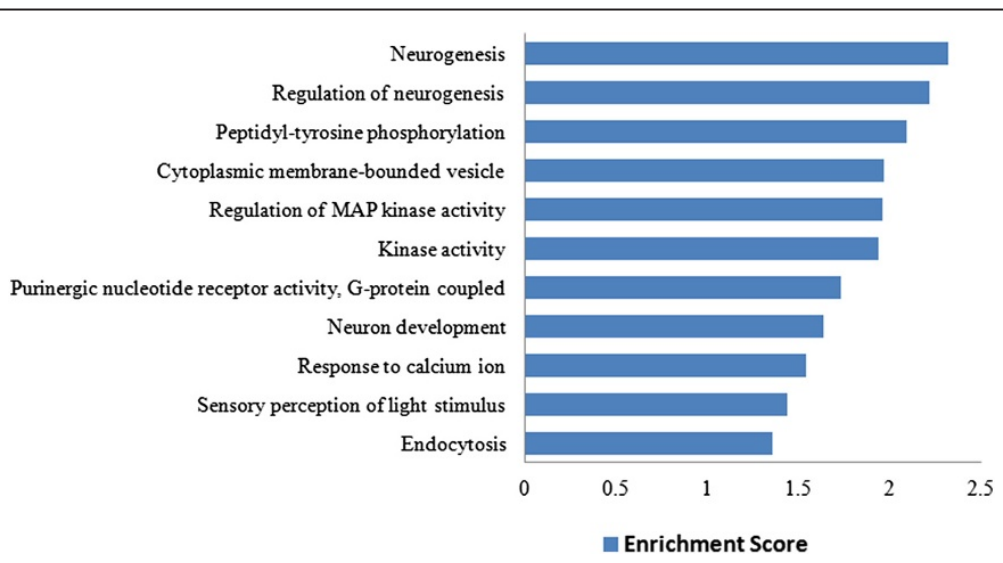

Figure 5 Clustering of GO terms: significantly over represented top 11 functionally annotated clusters from biological process, cellular component and molecular function of 108 proteins. 


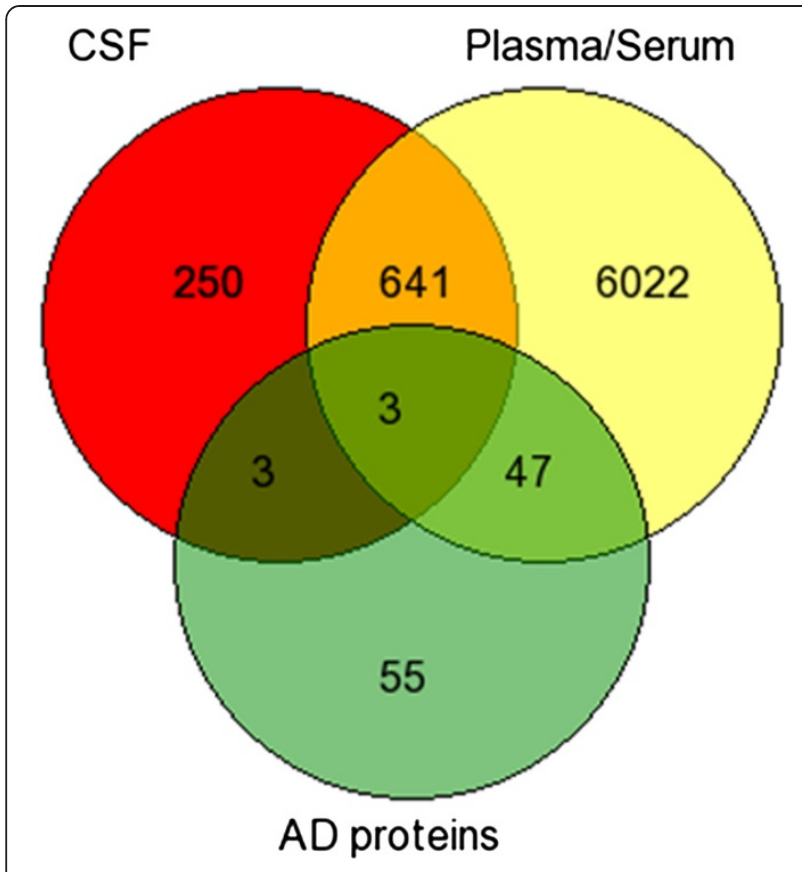

Figure 6 Putative AD specific biomarkers. The venn diagram depicts overlap among putative 108 AD proteins, proteins from CSF and plasma proteome.

cases and 802 controls. This collection was included in the first stage study by Fung et al. [56], and the expanded study by Simon-Sanchez et al. [57,58]. A total of 7,943 SNPs (stage I) were selected for further analysis, with $\mathrm{p}$ value < 0.01, from raw data comprising total of 453,217 SNPs.

For GWE dataset, we selected the gene expression data from NCBI GEO database (GSE20295) (www.ncbi.nlm. nih.gov/geo) [59] for analysis. It contained gene expression profiling data in post-mortem tissue of three brain regions (the substantia nigra, putamen, and Brodmann's area 9) from matched groups of 15 neuropathologically confirmed PD and 15 controls with no history of major brain illness.

The analysis of three PD datasets using rank based scoring method led us to the identification of 59 putative target genes from the overlap of 1528 genes from GWL, 2882 genes from GWA and 2923 genes from GWE which could have significant association with PD development and progression (Figure 7a). The entire list of 59 genes is provided in Additional file 8. The comparison of $108 \mathrm{AD}$ and 59 PD putative candidate genes resulted in only 2 common genes (ABCA1 and LPAR1) between the two groups (Figure $7 \mathrm{~b}$ ).

\section{Discussion}

$\mathrm{AD}$ is a complex polygenic disorder with lack of understanding of natural course of the disorder and absence of reliable biomarkers that can predict disease onset and progression. Although, genome-wide studies, such as genetic linkage, association and expression, have allowed unbiased identification of candidate genes and pathways

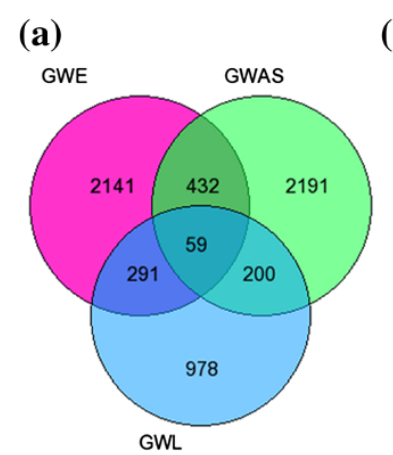

(b)

Figure 7 Prioritized putative PD candidate genes and overlap with prioritized $A D$ candidate genes. (a) The venn diagram represents the genes in the three individual datasets and overlapping 59 putative PD target genes identified by integrated analysis of the three datasets. (b) The venn diagram represents the overlapping genes among $\mathrm{AD}$ and PD putative target genes.

associated with AD development and progression, susceptibility loci or genes for AD with clinical significance have not yet been reported. This can be attributed to certain limitations associated with these methods. For instance, linkage studies require large, multi-generational pedigrees within which both affected and unaffected individuals are required for testing and even in such cases, this approach yields only regions of linkage and not the causative gene [60-62].This suggests that only a fraction of the genes, significant in these analyses, are causal genes. On the other hand, GWA studies often lack statistical power to detect SNPs with small effect size and therefore cannot detect all causal genes [63]. Further, in case of gene expression studies, identified genes are expected to contain a mix of causal and the differentially expressed genes because of the ripple effect of the causal genes [64]. The huge amount of $\mathrm{AD}$ specific genetic data accumulated in the past decade also indicates involvement of multiple pathways wherein each gene confers only a modest risk. Therefore, integration of datasets from multiple disciplines may lead to identification of candidate genes from different pathways and may provide an opportunity to uncover the biological functions and molecular mechanisms underlying AD through PPI network and GO analysis.

In this work, we presented a framework for integrated analysis of multi-dimensional datasets by using a rank based scoring method. First, we retrieved and analysed data from three datasets -GWL, GWA and GWE, based on the assumption that genes identified by all the three experimental technique might be significantly involved in $\mathrm{AD}$ pathology. Then, we used a ranked based method in which overlapping genes were first identified in all the three datasets and then each gene was assigned cumulative rank score $\left(S_{R}\right)$, based on addition of corresponding rank in individual datasets. The genes in each datasets were ranked based on either $\mathrm{p}$ values or scores. Finally, 
the genes were ranked based on their $S_{R}$ with gene having lower $\mathrm{S}_{\mathrm{R}}$ getting the higher rank. This analysis led us to the identification of 108 ranked genes from the overlap of 2729 genes from GWL, 1686 genes from GWA and 7961 genes from GWE which might serve as putative target genes having significant association with $\mathrm{AD}$ development and progression.

A majority of top ranked putative candidate genes have been found to be significantly associated with molecular mechanism and pathways related to AD development and progression and may serve as critical candidates for predicting $\mathrm{AD}$ risk. For instance, first ranked RPN1 gene encodes for a type I integral membrane protein, ribophorin that have been shown to directly interact with opioid receptors (OR). Overexpression of RPN1 is reported to enhance cell surface expression of $\delta \mathrm{OR}$ and $\mu \mathrm{OR}$ but not that of $\kappa O R$ [65]. Significant reductions in $\mu \mathrm{OR}$ binding are observed in the subiculum and HIP regions of brain from $\mathrm{AD}$ cases as compared to controls. Further, binding of $\delta \mathrm{OR}$ is also found to be decreased in the amygdala and putamen of $\mathrm{AD}$ brains [66]. In addition, $\delta \mathrm{OR}$ have been associated with increased processing of amyloid beta $(A \beta)$ precursor protein (APP) by BACE1 and $\gamma$-secretase, but not that of Notch, N-cadherin or APLP1. Moreover, knockdown or blocking of $\delta \mathrm{OR}$ in $\mathrm{AD}$ mouse model decreases secretase activities and abolishes $A \beta$ pathology and $A \beta$-dependent behavioral abnormalities [67]. Second ranked gene, $R G S 4$, encodes for regulator of $\mathrm{G}$ protein signalling 4 protein, is reported to be involved in neuronal calcium dependent signaling, a cellular process related to both $\mathrm{AD}$ and aging [68]. In parietal cortex of AD subjects, $53 \%$ and $40 \%$ lower levels of RGS4 and Gq/11 proteins is found as compared to age-matched controls. Further, it was proposed that alteration of dynamic equilibrium between the cytosolic and membrane levels of RGS4 and $\mathrm{Gq} / 11$ may lead to the regional differences in the coupling of muscarinic $\mathrm{M} 1$ receptors in $\mathrm{AD}$ which in turn may lead to variable response to currently available cholingeric treatment strategies [69]. HIP1 gene encodes for Huntingtin interacting protein 1 (HIP1) that is predominantly expressed in brain and is proposed as a novel brain tumor marker that interacts with EGFR [70]. In a published genome-wide study of aging, rs17149227 ( $\mathrm{p}$ value $<10^{-5}$ ) close to HIP1 gene, is found to be associated for time to death from meta-analysis of 9 cohorts [71]. Mills et al. (2005) proposed that transcriptional deregulation of HIP1 may play a significant role in the pathogenesis of neurodegenerative diseases [72].

A recently found strong LOAD candidate is $P T K 2 B /$ $C A K B / F A K 2 / P Y K 2$ gene that encodes for a cytoplasmic protein tyrosine kinase, which is highly expressed in the CNS, particularly in HIP [73]. A $\beta$ fibrils has been shown to induce THP-1 cells resulting in the stimulation of PYK2 tyrosine phosphorylation as a consequence of Lyn and Syk activation, intracellular calcium release, and PKC stimulation [74]. Activation of CAKb/Pyk2 is required for inducing long-term potentiation (LTP) in CA1 HIP neurons which may depend upon downstream activation of Src to upregulate N-methyl-D-aspartatetype (NMDA) glutamate receptors [75-77]. Further, in the case of $\mathrm{AD}$, the immunoreactivity for c-Jun is found to be elevated in diseased brain [78,79] and interestingly, PYK2 represents a stress sensitive mediator of c-Jun Nterminal kinase (JNK) signaling pathways.

ICA1 encodes for $69 \mathrm{kDa}$ islet cell autoantigen, a BAR (Bin/amphiphysin/Rvs)-domain-containing protein with highest expression levels in brain, pancreas, and stomach mucosa [80]. It is identified as the major binding partner of protein PICK1 (protein interacts with C-kinase 1). ICA1 regulates AMPA receptor trafficking, an important mechanism underlying synaptic plasticity, by forming heteromeric ICA69-PICK1 complexes and preventing formation of PICK1- PICK1 homomeric complexes [81]. Spitzenberger et al. demonstrated that mutation of ICA69 homologue gene ric-19 in C. elegans leads to impairment of acetylcholine release at neuromuscular junctions suggesting role of ICA69 in neuroendocrine secretion [82]. $A M P H 1$ gene encodes for protein amphiphysin I, an important regulator for synaptic vesicle endocytosis (SVE) when massive amounts of $\mathrm{Ca}^{2+}$ flow into presynaptic terminals, a phenomenon observed in AD [83]. In AMPH1 knockout mice, decreased synaptic vesicle recycling efficiency and cognitive deficits has been observed [84]. In a recent study, AMPH1 level is found to be reduced in $\mathrm{AD}$ brain regions known to accumulate aggregates of hyperphosphorylated tau proteins [85]. Further, stimulated neurons are also shown to abnormally accumulate amphiphysin, at the membrane during $\mathrm{A} \beta$ treatment [86].

Interestingly, ATP5H/KCTD2 locus is reported as the major candidate gene associated with $\mathrm{AD}$ pathogenesis in the study by Boada et al. [44] that is used in this study as the replication dataset. ATP5H gene encodes for mitochondrial ATP synthase that plays an important function in mitochondrial energy production and neuronal hyperpolarization during cellular stress conditions, such as hypoxia or glucose deprivation [44]. EGFR gene encodes for epidermal growth factor receptor protein, a cell surface protein that binds to epidermal growth factor. It has been put forward as a preferred target for treating amyloid beta induced memory loss in a recent study by Wang $\mathrm{L}$ et al. [87]. Interestingly, it has come up as one of the most significant candidate in our study occurring in top 10 ranked genes among 108 candidates, as central hub node in cluster and in the overlap of AD protein and proteins from plasma and CSF proteome. Increased expression of EGFR is observed in fibroblasts deficient in PS/gamma-secretase activity or APP expression [88]. Further, studies also indicate role of PS1 in trafficking 
and turnover of EGFR as well as perturbed endosomallysosomal trafficking in cell cycle control and Alzheimer disease and suggest potential pathogenic effects of elevated EGFR [89]. In a recent study, altered EGFR transcript levels are reported among APOE4 (high risk) when compared to APOE3 (low risk) genotype groups [90].

A major candidate gene for LOAD due to its role in cholesterol transport and metabolism is $A B C A 1$ gene that encodes for ATP-binding cassette transporter A1, a membrane-associated protein. Increased expression of $A B C A 1$ is highly correlated with severity of dementia in AD HIP [91]. Further, ABCA1 has been shown in mouse models of $\mathrm{AD}$ to enable the clearance of $\mathrm{A} \beta$ from the brain, through its role in the apolipoprotein (APOE) lipidation in the CNS [92-95]. In APP transgenic mice, $A B C A 1$ deficiency increased $A \beta$ deposition in the brain paralleled by decreased levels of ApoE [96]. In addition, ABCA1 is also found to be up-regulated in primary mouse cortical neurons and cultured astrocytes in response to oligomeric A $\beta 42[97,98]$. Recent studies pointed out that ABCA1 mediates the beneficial effects of the liver $\mathrm{X}$ receptor (LXR) agonist GW3965 on object recognition memory and amyloid burden in APP/PS1mice [99,100]. Based on strong evidence the LXR-ABCA1-APOE regulatory axis is now considered a promising therapeutic target in $\mathrm{AD}$ [101]. However, a meta-analysis report of 13 studies involving a total of 12,248 subjects failed to find association of common SNPs in $A B C A 1$ with AD risk [102]. In contrast, Lupton et al. in a very recent study sequenced all $A B C A 1$ coding regions in 311 LOAD cases and 360 control individuals of Greek ethnicity and observed significantly higher proportion of rare non-synonymous variants in control individuals compared to AD cases. These findings suggest that high throughput sequencing may identify rare variants that are left undetected by GWAS [92]. $A C T B$ gene encodes for protein $\beta$-actin. It is found to have the worst candidate with reliable expression among a set of suitable endogenous reference genes (ERG) in human post-mortem brain when used for the expression analysis of potential candidate genes associated with AD [103]. $A C T B$ was found to be upregulated by 10.2 folds in $\mathrm{AD}$ cerebral cortex compared with age-matched control brain [104]. Further, immunoprecipitation of proteins from AD and control brain showed oxidative modification of $\beta$ actin in the AD brain [105]. In addition, $\beta$-Secretasecleaved APP is shown to accumulate at actin inclusions in neurons induced by stress or $A \beta$ [106]. Several recent studies also indicate that abnormalities of actin cytoskeleton may play a critical role in AD pathology by mediating synaptic degeneration $[107,108]$.

We aimed to identify direct protein interactors of proteins encoded by identified 108 candidate genes by PPI network modelling with an assumption that they might provide important biological information related to molecular mechanisms underlying AD development and progression. PPI network was obtained by using APID2NET plugin in Cytoscape and included 640 protein nodes and 2214 edges. It was converted to a layered network based on subcellular localization information. We observed that majority of the proteins were localized in cytoplasm followed by nucleus. Further, we applied MCL clustering algorithm to identify functional modules with proteins forming hub nodes (EGFR, ACTB, CDC2, IRAK2, APOE, ABCA1 and AMPH) which might serve as important candidates related to AD [50]. For instance, CDC2 $[109,110]$, IRAK2 [111] have been reported in recently published studies with suggestive role in AD pathogenesis. GO analysis was also carried out using 108 genes to identify biological processes, molecular functions and cellular components. Top 11 annotation clusters with enrichment score $>1.3$ included genes involved in diverse biological processes related to AD such as neurogenesis (DFNB31, PTK2B, RET, DLL3, APOE, CRX, ACTB, NRP1, LMX1A, $P I P 5 K 1 C, Z N F 488)$, regulation of neurogenesis (DLL3, $A P O E, C R X, N R P 1, L M X 1 A, Z N F 488)$, peptidyl tyrosine phosphorylation (TYK2, PTK2B, DDR2, SYK), cytoplasmic membrane-bounded vesicles (PLA2G4A, ABCA1, HIP1, AMPH, HGF, SFTPD, EGFR, ICA69, ATP8B3, RPN1), regulation of MAP kinase activity (PTK2B, LPAR1, APOE, RGS4, HGF, EGFR, SYK), kinase activity (PTK2B, TYK2, NME8, DDR2, NRP1, PIP5K1C, EGFR, RET, PAK4, IPMK, POLR2E, ADK, SYK), purinergic nucleotide receptor activity, G-protein coupled (SUCNR1, P2RY12, P2RY14), neuron development (DFNB31, PTK2B, RET, ACTB, NRP1, LMX1A, PIP5K1C, EGFR), response to calcium ion (PLA2G4A, PTK2B, ACTB, EGFR), sensory perception of light stimulus (DFNB31, RGS16, PCDH15, CRX, RIMS1, ELOVL4, OPN5), endocytosis (ABCA1, APOE, HIP1, AMPH, ELMO1, SFTPD).

In addition, potential CSF and plasma/serum based biomarkers were identified from the overlap of 108 and $640 \mathrm{AD}$ proteins separately with proteins from CSF and plasma proteome. This resulted in the identification of 3 proteins and 38 proteins as potential biochemical biomarkers for AD among 108 and 640 identified protein datasets, respectively. Among these proteins, the CSF or plasma level of, APOE [112-120], EGFR [121] proteins have been reported to be altered in previous AD studies.

For validation of our approach, we have applied our rank based scoring method to identify $\mathrm{PD}$ candidate genes using three (GWL, GWA and GWE) datasets and then we compared PD candidate genes with those identified in analysis of AD datasets to check the robustness of our approach. We failed to find significant overlap in genes between $\mathrm{AD}$ and PD dataset in our study, which is further substantiated by a recent meta-analysis carried out by Moskvina et al. that combined the AD and PD GWA studies and failed to identify any significant 
evidence to support a common genetic risk between $\mathrm{AD}$ and PD [122]. Further, the author failed to find loci that associate with increased risk of causing both PD and AD. In addition, it is proposed that the pathological overlap among AD and PD proteins may occur at a later stage during disease progression suggesting interaction of genes from downstream cascade with susceptibility genes that increase the risk of each disease [122]. Few studies investigated simultaneous co-occurrence of $\mathrm{AD}$ and $\mathrm{PD}$ in families but yielded inconsistent results. In general, studies have reported either no risk of $\mathrm{AD}$ in the relatives of subjects with PD or an increased risk of $\mathrm{AD}$ in younger subjects with $\mathrm{PD}$ or those with cognitive impairment [123-125].

The recent association of several genes identified in our study to AD provides an immediate support of our work and prioritization of such candidates clearly indicates the efficiency and importance of our method. Our approach provides a list of AD candidate genes that are promising for further analysis by exploration of biological functions. The other most common candidate gene prioritization approaches use single-dimentional data-source and are based on direct PPI of the genes that are being studied. However, currently only $\sim 10 \%$ of all human PPI have been described which is a major drawback of these approaches [126]. Here, we have tried to address these issues by using multi-dimensional data and exploiting the clustering of PPI network for identification of functional modules. Still, the limitations of our study include constraints in the gene annotation in the selected linkage regions and the availability of raw genome-wide data. Owing to these limitations, it is possible that a few putative candidate genes may have been missed out in this study during the screening process. Further, extensive experimental validation of candidate genes from our analysis is warranted in future.

\section{Conclusion}

To achieve better identification of complex disease associated genes, it is imperative to use integrative approach with disease specific methodologies. We performed integrated analysis of three different datasets - GWL,GWA and GWE and developed a rank based scoring method which resulted in the identification of 108 putative AD candidate genes. Further, network analysis led to a PPI with 640 nodes and clustering of this network resulted in 6 significant clusters with 7 genes forming central hub nodes. Finally, 3 biochemical biomarkers were also identified from the overlapping genes between 108 AD proteins and proteins in CSF-plasma proteome. EGFR and $A C T B$ were found to be the two most significant $\mathrm{AD}$ risk genes ranked 8 and 10 among 108 genes respectively, present as central hub nodes in respective clusters and also as potential biochemical biomarker. We believe that our findings would provide a wealth of information for future experimental and clinical validation in $\mathrm{AD}$ pathogenesis and therapeutics.

\section{Methods}

\section{Genetic linkage data retrieval and processing}

We used linkage regions from AlzGene database which were based on the results of meta-analyses [32] and combined analysis [33] of previously published genomewide linkage (GWL) data. In our study, linkage regions with LOD scores $\geq 2.0$ or $\mathrm{p}$ value $<0.05$ linked to $\mathrm{AD}$ were selected for further analysis. The chromosomal coordinates for each linkage region were retrieved using UCSC genome browser. These were then used to extract genes from GeneWanderer web server [41] which provides a method for prioritization of candidate genes by using four different ranking strategies (random walk, diffusion kernel, shortest path and direct interaction) on a PPI network. We used random walk since it has been showed to outperform the others $[41,127,128]$.

\section{Genome wide association data retrieval and processing}

We used SNPs with pre-computed $\mathrm{p}$ values from a recently published GWA study performed under the International Genomics of Alzheimer's Project (I-GAP) banner [34]. The data are available for download from the following link: http://www.pasteur-lille.fr/en/recherche/u744/ Igap_stage1.zip. The study performed meta-analysis on genotyped and imputed data $(7,055,881$ SNPs) from 4 previously published GWAS [ADGC, CHARGE, EADI, GERD consortium datasets] comprising 17,008 cases and 37,154 controls (stage 1). A total of 19,532 SNPs were found to be associated with $A D$ risk and having $p$ value $<1 \times 10^{-3}$ after stage 1 meta-analysis. For replication analysis, we have used another GWA dataset from Boada et al. [44] that included genotyped and imputed SNPs $(1,098,485)$ from 7 reported GWAS (Antúnez et al. [129], TGEN [130], ADNI [131], genADA [132], NIA [133], Pfizer [134], GERAD [135]) comprising 8082 cases and 12040 controls for stage I meta-analysis. With this cohort used in stage I analysis with $\mathrm{P}<0.001,1202$ SNPs were obtained. These data are available as Supplementary Table S4 in the study by Baoda et al. [44].

The SNPs were mapped to genes using NCBI variation reporter tool, SCAN database [42] and SPOT tool [43]. SNPs, which remained unmapped, were excluded from further analysis. SPOT tool implements the Genomic Information Network prioritization method and provides a prioritization score that represents an order of magnitude change in $\mathrm{p}$ value from a test for association. SPOT score takes into account SNPs functional properties (including nonsense, frameshift, missense and 5' and 3'UTR designations), impact of an amino acid substitution on the properties of the protein product from PolyPhen server [136,137], evolutionary conserved regions from 
ECRbase [138], all possible LD proxies - SNPs with $\mathrm{r}^{2}$ over a predefined threshold in a specific HapMap sample [139].

\section{Gene expression data retrieval and processing}

We retrieved the gene expression data from NCBI GEO (GSE5281) database (www.ncbi.nlm.nih.gov/geo) [38]. It contained expression data from six functionally and anatomically distinct regions in human brains, including EC, HIP, MTG, PC, SFG and VCX. The data included 161 samples and each brain region contains $\mathrm{AD}$ cases versus normal controls. GEO2R web application, available at http://www.ncbi.nlm.nih.gov/geo/geo2r/, was used for Rbased analysis of GEO data [38]. The numbers of samples in each region of control/affected cases were 13/10 of EC, 13/10 of HIP, 12/16 of MTG, 13/9 of PC, 11/23 of SFG and $12 / 19$ of VCX. In our study data from all 6 regions were analysed separately and then merged. For replication analysis, we used another GWE dataset - GSE15222 that comprised expression data from post-mortem brain cortical regions of 176 late-onset AD cases and 188 controls. On the GEO2R web interface, after the GSE5281 series were specified, a table populated with sample characteristics appears. The AD and control sample groups were designated to compare for each brain region separately. Default analysis setting with Benjamini \& Hochberg (False discovery rate) for $\mathrm{p}$ value adjustments was used.

Probe sets that were not associated with known genes were removed from further analysis. If multiple probe sets represented the same gene and they showed same direction of expression, the probe set with the highest variance was used. If the direction of expression for multiple probe set was different then they were excluded from further analysis. The genes with adjusted $\mathrm{p}$ value $<0.05$ and fold change $\geq 2.0$ for upregulated genes and $\leq 0.5$ for downregulated genes were selected. The genes from the six brain regions were merged and duplicates were removed.

\section{Filtering and scoring of genes from data sets}

The genes in all the three datasets were assigned HGNC (HUGO Gene Nomenclature Committee) ids separately [140]. The pseudogene, hypothetical, loci, non-coding RNA, non-protein coding genes, non-functional proteins, open reading frames (orf), chromosome $\mathrm{X}$ (Xp; Xq), withdrawn entries, antisense RNA, microRNA, uncharacterized genes were excluded from each data set for further analysis. The genes were ranked in GWL and GWA datasets by score and weighted p value obtained through GeneWanderer [41] and SPOT web servers [43], respectively. The genes in GWE dataset were ranked by adjusted or unadjusted $\mathrm{p}$ value obtained after analysis with GEO2R web tool. The genes, with higher weight or lower $p$ value, were assigned higher ranks. The genes, appearing in all the three dataset, were identified and cumulative rank score for each gene was calculated using the following equation -

$$
S_{R_{i}}=r_{G W E_{i}}+r_{G W L_{i}}+r_{G W A S_{i}}
$$

where,

$$
S_{R_{i}}=\text { Cumulative rank score for gene }{ }_{i}
$$$$
\text { (where } i=1,2,3 \ldots . .108 \text { ) }
$$

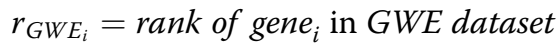

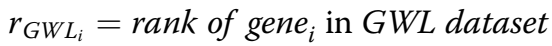

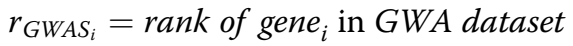

Based on their rank score the genes were re-ranked with one having the lower cumulative rank score getting the higher rank.

\section{Protein-protein Interaction network, layering and network analysis}

To identify the direct interacting partners of the putative genes identified in this study from integrative analysis of three different data types, we built a PPI network using plugin APID2NET in Cytoscape version 2.8.1 [48] as described by Silla et al. [141]. Briefly, the APID2NET (APID) server creates PPI network of user-provided proteins using literature-curated protein interaction information from various databases such as BIND, BioGrid, DIP, HPRD, IncAct and MINT. UniProt ids of the 108 putative AD target genes were retrieved using uniprot id mapping tool (http://www.uniprot.org) [142] and provided as input ids in APID server to build the interaction network. For creating a PPI network, we first considered only those interactions supported by at least two experimental validations in order to minimize false-positive interactions. However, for proteins lacking interacting partners validated by two experiments, the interacting partners with one experimental validation were considered resulting in another PPI network. Three Cytoscape tools viz Advance Network Analyzer [143], Cerebral [52] and clusterMaker [37] were then applied for modelling PPI network. The Advanced Network Merge was used to model a final PPI network by taking union of both the PPI networks and for removal of duplicated edges and self loops. Isolated nodes were also manually removed from the final PPI network. Protein sub-cellular localization information for 635 proteins were retrieved from uniprot database [142] and for remaining 56 genes from human protein atlas [144] which were imported as node attributes in cytoscape. Then Cytoscape plugin "Cerebral" v.2.8.2 was applied to the final network to layout all nodes according to their sub-cellular localization such as plasma membrane, cytoplasm, nucleus, golgi apparatus, extracellular matrix, endoplasmic reticulum 
(ER), lysosome and mitochondria. Further, Markov Cluster algorithm (MCL) $[50,145]$ which was implemented in the "clusterMaker" v.1.9 plugin [37] in cytoscape was used on the PPI to create clusters with the hub nodes. The MCL algorithm has been used specifically to cluster simple graphs and weighted graphs by calculating successive powers of the associated adjacency matrix also called as Markov matrices which capture the mathematical concept of random walks on a graph [50].

\section{GO annotation analysis}

To assess the identified candidate genes in the context of GO, the DAVID functional annotation tool (version 6.7) $[38,39]$ was used. The functional annotation clustering of significantly over-represented GO term: cellular compartment (CC), molecular function (MF) and biological process (BP) was retrieved by using options GOTERM_CC_ALL, GOTERM_MF_ALL and GOTERM_BP_ALL. The default setting parameters and multiple corrections by the Benjamini method were used to determine the significant enrichment score of $1.3[38,39]$.

\section{AD putative biochemical biomarkers analysis}

To identify putative biochemical biomarker associated with AD, CSF and plasma proteins were retrieved from Sys-BodyFluid Database [146]. The 108 target genes were mapped to their corresponding uniprot ids using ID mapping tool available at http://www.uniprot.org [142]. The venn diagram of the overlapping proteins in all the three datasets (GWL,GWA and GWE) was created using GeneVenn tool [147] by taking intersection among these data sets.

\section{Additional files}

Additional file 1: AD GWA and GWE replication datasets. The file contains the list of 294 genes from AD GWA replication dataset (Boada et al.) and list of 182 genes from AD GWE replication dataset (Webster et al., GEO:GSE15222).

Additional file 2: Final list of AD genes from three data sets and final list of ranked 108 genes. The file contains the list of genes from three datasets, final overlapping 108 genes ranked by their cumulative rank score.

Additional file 3: Venn diagrams of overlapping genes from independent analysis of genes from 6 brain region separately with GWA and GWL datasets. The file contains Venn diagrams of genes from three datasets, final overlapping 108 genes ranked by their cumulative rank score.

Additional file 4: List of overlapping genes from independent analysis of genes from 6 brain region separately with GWA and GWL datasets. The file contains the list of genes from three datasets, final overlapping 108 genes ranked by their cumulative rank score.

Additional file 5: Clusters identified from PPI using MCL algorithm implemented in clusterMaker. The file details the 69 clusters identified by MCL algorithm from the PPI containing 640 genes.
Additional file 6: Annotation clusters from DAVID. The file contains top 11 and 10 annotation clusters with GO analysis from DAVID for 108 and 640 genes respectively.

Additional file 7: Putative AD specific biomarkers among 640 AD proteins and proteins from CSF and plasma proteome. The file contains Venn diagram showing overlap of 640 AD proteins and proteins from CSF and plasma proteome.

Additional file 8: Final list of PD genes from three data sets and final list of $\mathbf{5 9}$ candidate overlapping genes. The file contains the list of genes from three datasets, final overlapping 59 candidate genes.

\section{Abbreviations}

AD: Alzheimer's disease; GWE: Genome Wide Expression; GWL: Genome Wide Linkage; GWA: Genome Wide Association; APP: Amyloid beta (A4) precursor protein; PSEN1: Presenilin 1; PSEN2: Presenilin 2; CDC2: Cyclin-dependent kinase 1; IRAK1: Interleukin-1 receptor-associated kinase 1; CSF: Cerebrospinal fluid; LOAD: Late onset Alzheimer's disease; PPI: Protein-Protein Interaction; SNP: Single nucleotide polymorphism; MCL: Markov Clustering algorithm; GO: Gene Ontology.

\section{Competing interest}

The authors declare that they have no competing interests.

\section{Authors' contributions}

PT conceived, designed, processed, interpreted the data and wrote the manuscript. YS and SG have contributed in work design, interpretation and manuscript writing. RK has conceived and supervised the study. MG, RA and SK have contributed by critical evaluation of the study and improving the manuscript. All the authors read and approved the final manuscript.

\section{Acknowledgement}

We thank Prof. Samir K. Brahmachari (IGIB) for his vision and Dr. Rajesh Gokhale, Director, Institute of Genomics and Integrative Biology (CSIR) for his support. We appreciate Dr. Shantanu Sengupta (IGIB) for critical evaluation of the manuscript. Financial support from Council of Scientific and Industrial Research (CSIR) (BSC0123) is duly acknowledged. PT, YS and SG acknowledge CSIR, Govt. of India for providing their fellowships. We thank the anonymous reviewers for their helpful suggestions for improving the manuscript.

\section{Author details}

'Genomics and Molecular Medicine Unit, Institute of Genomics and Integrative Biology (IGIB), Council of Scientific and Industrial Research (CSIR), Mall Road, Delhi 110 007, India. ${ }^{2}$ Department of Neurochemistry, Institute of Human Behaviour and Allied Sciences, Dilshad Garden, Delhi, India. ${ }^{3}$ Department of Neurology, Institute of Human Behaviour and Allied Sciences, Dilshad Garden, Delhi, India.

Received: 1 July 2013 Accepted: 21 February 2014 Published: 15 March 2014

\section{Reference}

1. Crews L, Masliah E: Molecular mechanisms of neurodegeneration in Alzheimer's disease. Hum Mol Genet 2010, 19(R1):R12-R20.

2. Ghebranious N, Mukesh B, Giampietro PF, Glurich I, Mickel SF, Waring SC, McCarty CA: A pilot study of gene/gene and gene/environment interactions in Alzheimer disease. Clin Med Res 2011, 9(1):17-25.

3. Mayeux R, Stern Y: Epidemiology of Alzheimer disease. Cold Spring Harb Perspect Med 2012, 2(8). doi:10.1101/cshperspect.a006239.

4. Gatz M, Reynolds CA, Fratiglioni L, Johansson B, Mortimer JA, Berg S, Fiske A, Pedersen NL: Role of genes and environments for explaining Alzheimer disease. Arch Gen Psychiatry 2006, 63(2):168-174.

5. Pedersen NL, Posner SF, Gatz M: Multiple-threshold models for genetic influences on age of onset for Alzheimer disease: findings in Swedish twins. Am J Med Genet 2001, 105(8):724-728.

6. Ertekin-Taner N: Genetics of Alzheimer's disease: a centennial review. Neurol Clin 2007, 25(3):611-667. v.

7. Guerreiro RJ, Gustafson DR, Hardy J: The genetic architecture of Alzheimer's disease: beyond APP. PSENs and APOE. Neurobiol Aging 2012, 33(3):437-456. 
8. Bertram L, McQueen MB, Mullin K, Blacker D, Tanzi RE: Systematic metaanalyses of Alzheimer disease genetic association studies: the AlzGene database. Nat Genet 2007, 39(1):17-23.

9. Wang $X$, Michaelis ML, Michaelis EK: Functional genomics of brain aging and Alzheimer's disease: focus on selective neuronal vulnerability. Curr Genomics 2010, 11(8):618-633.

10. Reddy PH, McWeeney S: Mapping cellular transcriptosomes in autopsied Alzheimer's disease subjects and relevant animal models. Neurobiol Aging 2006, 27(8):1060-1077

11. Tsapakis EM, Basu A, Aitchison KJ: Transcriptomics and proteomics: advancing the understanding of psychiatric pharmacogenomics. Clinical Neuropsychiatry 2004, 1(2):117-124.

12. Hallock $P$, Thomas MA: Integrating the Alzheimer's disease proteome and transcriptome: a comprehensive network model of a complex disease. OMICS 2012, 16(1-2):37-49.

13. Raj T, Shulman JM, Keenan BT, Chibnik LB, Evans DA, Bennett DA, Stranger BE, De Jager PL: Alzheimer disease susceptibility loci: evidence for a protein network under natural selection. Am J Hum Genet 2012, 90(4):720-726.

14. Jia P, Ewers JM, Zhao Z: Prioritization of epilepsy associated candidate genes by convergent analysis. PLoS One 2011, 6(2):e17162

15. Jain P, Vig S, Datta M, Jindel D, Mathur AK, Mathur SK, Sharma A: Systems biology approach reveals genome to phenome correlation in type 2 diabetes. Plos One 2013, 8(1):e53522.

16. Sharma A, Chavali S, Tabassum R, Tandon N, Bharadwaj D: Gene prioritization in Type 2 Diabetes using domain interactions and network analysis. BMC Genomics 2010, 11:84

17. Gorlov IP, Gallick GE, Gorlova OY, Amos C, Logothetis CJ: GWAS meets microarray: are the results of genome-wide association studies and gene-expression profiling consistent? Prostate cancer as an example. PLoS One 2009, 4(8):e6511.

18. Jia $\mathrm{P}, \mathrm{Kao} C F, \mathrm{Kuo} \mathrm{PH}$, Zhao Z: A comprehensive network and pathway analysis of candidate genes in major depressive disorder. BMC Syst Biol 2011, 5(3):S12.

19. Sun J, Jia P, Fanous AH, Webb BT, van den Oord EJ, Chen X, Bukszar J, Kendler KS, Zhao Z: A multi-dimensional evidence-based candidate gene prioritization approach for complex diseases-schizophrenia as a case. Bioinformatics 2009, 25(19):2595-6602.

20. Maver A, Peterlin B: Positional integratomic approach in identification of genomic candidate regions for Parkinson's disease. Bioinformatics 2011, 27(14):1971-1978.

21. Wang X, Gulbahce N, Yu H: Network-based methods for human disease gene prediction. Brief Funct Genomics 2011, 10(5):280-293.

22. Bakir-Gungor B, Sezerman OU: A new methodology to associate SNPs with human diseases according to their pathway related context. PLoS One 2011, 6(10):e26277.

23. Liang D, Han G, Feng $X$, Sun J, Duan Y, Lei H: Concerted perturbation observed in a hub network in Alzheimer's disease. PLoS One 2012 7(7):e40498.

24. Regan K, Wang K, Doughty E, Li H, Li J, Lee Y, Kann MG, Lussier YA: Translating Mendelian and complex inheritance of Alzheimer's disease genes for predicting unique personal genome variants. J Am Med Inform Assoc 2012, 19(2):306-316.

25. Liu ZP, Wang Y, Zhang XS, Chen L: Identifying dysfunctional crosstalk of pathways in various regions of Alzheimer's disease brains. BMC Syst Biol 2010, 4:S11.

26. Liu ZP, Wang Y, Zhang XS, Xia W, Chen L: Detecting and analyzing differentially activated pathways in brain regions of Alzheimer's disease patients. Mol Biosyst 2011, 7(5):1441-1452.

27. Goni J, Esteban FJ, de Mendizabal NV, Sepulcre J, Ardanza-Trevijano S, Agirrezabal I, Villoslada P: A computational analysis of protein-protein interaction networks in neurodegenerative diseases. BMC Syst Biol 2008, 2:52

28. Liu Y, Patel S, Nibbe R, Maxwell S, Chowdhury SA, Koyuturk M, Zhu X, Larkin EK, Buxbaum SG, Punjabi NM, Gharib SA, Redline S, Chance MR: Systems biology analyses of gene expression and genome wide association study data in obstructive sleep apnea. Pac Symp Biocomput 2011:14-25.

29. Zhu W, Yang L, Du Z: Layered functional network analysis of gene expression in human heart failure. PLoS One 2009, 4(7):e6288.

30. Sun J, Zhao Z: A comparative study of cancer proteins in the human protein-protein interaction network. BMC Genomics 2010, 11(3):S5.

31. Muhlberger I, Moenks K, Bernthaler A, Jandrasits C, Mayer B, Mayer G, Oberbauer R, Perco P: Integrative bioinformatics analysis of proteins associated with the cardiorenal syndrome. Int J Nephrol 2010, 2011:809378.

32. Butler AW, Ng MY, Hamshere ML, Forabosco P, Wroe R, Al-Chalabi A, Lewis CM, Powell JF: Meta-analysis of linkage studies for Alzheimer's disease-a web resource. Neurobiol Aging 2009, 30(7):1037-1047.

33. Hamshere ML, Holmans PA, Avramopoulos D, Bassett SS, Blacker D, Bertram L, Wiener H, Rochberg N, Tanzi RE, Myers A, Wavrant-De Vrièze F, Go R, Fallin D, Lovestone S, Hardy J, Goate A, O'Donovan M, Williams J, Owen MJ: Genome-wide linkage analysis of 723 affected relative pairs with late-onset Alzheimer's disease. Hum Mol Genet 2007, 16(22):2703-2712.

34. Lambert JC, Ibrahim-Verbaas CA, Harold D, Naj AC, Sims R, Bellenguez C, Jun G, Destefano AL, Bis JC, Beecham GW, Grenier-Boley B, Russo G, Thornton-Wells TA, Jones N, Smith AV, Chouraki V, Thomas C, Ikram MA, Zelenika D, Vardarajan BN, Kamatani Y, Lin CF, Gerrish A, Schmidt H, Kunkle B, Dunstan ML, Ruiz A, Bihoreau MT, Choi SH, Reitz C, et al: Meta-analysis of 74,046 individuals identifies 11 new susceptibility loci for Alzheimer's disease. Nat Genet 2013, 45(12):1452-1458.

35. Liang WS, Dunckley T, Beach TG, Grover A, Mastroeni D, Ramsey K, Caselli RJ, Kukull WA, McKeel D, Morris JC, Hulette CM, Schmechel D, Reiman EM, Rogers J, Stephan DA: Neuronal gene expression in non-demented individuals with intermediate Alzheimer's Disease neuropathology. Neurobiol Aging 2010, 31(4):549-566.

36. Liang WS, Dunckley T, Beach TG, Grover A, Mastroeni D, Ramsey K, Caselli RJ, Kukull WA, McKeel D, Morris JC, Hulette CM, Schmechel D, Reiman EM, Rogers J, Stephan DA: Altered neuronal gene expression in brain regions differentially affected by Alzheimer's disease: a reference data set. Physiol Genomics 2008, 33(2):240-256.

37. Morris JH, Apeltsin L, Newman AM, Baumbach J, Wittkop T, Su G, Bader GD, Ferrin TE: clusterMaker: a multi-algorithm clustering plugin for Cytoscape. BMC Bioinformatics 2011, 12:436.

38. da Huang W, Sherman BT, Lempicki RA: Systematic and integrative analysis of large gene lists using DAVID bioinformatics resources. Nat Protoc 2009, 4(1):44-57.

39. da Huang W, Sherman BT, Lempicki RA: Bioinformatics enrichment tools: paths toward the comprehensive functional analysis of large gene lists. Nucleic Acids Res 2009, 37(1):1-13.

40. Kent WJ, Sugnet CW, Furey TS, Roskin KM, Pringle TH, Zahler AM, Haussler D: The human genome browser at UCSC. Genome Res 2002, 12(6):996-1006.

41. Kohler S, Bauer S, Horn D, Robinson PN: Walking the interactome for prioritization of candidate disease genes. Am J Hum Genet 2008, 82(4):949-958.

42. Gamazon ER, Zhang W, Konkashbaev A, Duan S, Kistner EO, Nicolae DL, Dolan ME, Cox NJ: SCAN: SNP and copy number annotation. Bioinformatics 2010, 26(2):259-262.

43. Saccone SF, Bolze R, Thomas P, Quan J, Mehta G, Deelman E, Tischfield JA, Rice JP: SPOT: a web-based tool for using biological databases to prioritize SNPs after a genome-wide association study. Nucleic Acids Res 2010, 38(Web Server issue):W201-209.

44. Boada M, Antunez C, Ramirez-Lorca R, Destefano AL, Gonzalez-Perez A, Gayan J, Lopez-Arrieta J, Ikram MA, Hernandez I, Marin J, Galán JJ, Bis JC, Mauleón A, Rosende-Roca M, Moreno-Rey C, Gudnasson V, Morón FJ, Velasco J, Carrasco JM, Alegret M, Espinosa A, Vinyes G, Lafuente A, Vargas $L$, Fitzpatrick AL, for the Alzheimer's Disease Neuroimaging Initiative, Launer LJ, Sáez ME, Vázquez E, Becker JT: ATP5H/KCTD2 locus is associated with Alzheimer's disease risk. Mol Psychiatry 2013. doi:10.1038/mp.2013.86.

45. Barrett T, Wilhite SE, Ledoux P, Evangelista C, Kim IF, Tomashevsky M, Marshall KA, Phillippy KH, Sherman PM, Holko M, Yefanov A, Lee H, Zhang N, Robertson CL, Serova N, Davis S, Soboleva A: NCBI GEO: archive for functional genomics data sets-update. Nucleic Acids Res 2013 41(Database issue):D991-995.

46. Webster JA, Gibbs JR, Clarke J, Ray M, Zhang W, Holmans P, Rohrer K, Zhao A Marlowe L, Kaleem M, McCorquodale DS 3rd, Cuello C, Leung D, Bryden L, Nath P, Zismann VL, Joshipura K, Huentelman MJ, Hu-Lince D, Coon KD, Craig DW, Pearson JV, NACC-Neuropathology Group, Heward CB, Reiman EM, Stephan D, Hardy J, Myers AJ: Genetic control of human brain transcript expression in Alzheimer disease. Am J Hum Genet 2009, 84(4):445-58.

47. Shannon P, Markiel A, Ozier O, Baliga NS, Wang JT, Ramage D, Amin N, Schwikowski B, Ideker T: Cytoscape: a software environment for integrated models of biomolecular interaction networks. Genome Res 2003, 13(11):2498-2504.

48. Hernandez-Toro J, Prieto C, De las Rivas J: APID2NET: unified interactome graphic analyzer. Bioinformatics 2007, 23(18):2495-2497. 
49. Barsky A, Gardy JL, Hancock RE, Munzner T: Cerebral: a Cytoscape plugin for layout of and interaction with biological networks using subcellular localization annotation. Bioinformatics 2007, 23(8):1040-1042.

50. Van Dongen S: Graph clustering by flow simulation. PhD Thesis. The Netherlands: University of Utrecht; 2000

51. Nussbaum RL, Ellis CE: Alzheimer's disease and Parkinson's disease. N Engl J Med 2003, 348(14):1356-1364.

52. Mayeux R: Epidemiology of neurodegeneration. Annu Rev Neurosci 2003, 26:81-104.

53. Lill CM, Roehr JT, McQueen MB, Kavvoura FK, Bagade S, Schjeide BM Schjeide LM, Meissner E, Zauft U, Allen NC, Liu T, Schilling M, Anderson KJ, Beecham G, Berg D, Biernacka JM, Brice A, DeStefano AL, Do CB, Eriksson N, Factor SA, Farrer MJ, Foroud T, Gasser T, Hamza T, Hardy JA, Heutink P, Hill-Burns EM, Klein C, Latourelle JC, et al: Comprehensive research synopsis and systematic meta-analyses in Parkinson's disease genetics: the PDGene database. PLoS Genet 2012, 8(3):e1002548.

54. Rosenberger A, Sharma M, Muller-Myhsok B, Gasser T, Bickeboller H: Meta analysis of whole-genome linkage scans with data uncertainty: an application to Parkinson's disease. BMC Genet 2007, 8:44.

55. Tryka KA, Hao L, Sturcke A, Jin Y, Wang ZY, Ziyabari L, Lee M, Popova N, Sharopova N, Kimura M, Feolo M: NCBI's Database of Genotypes and Phenotypes: dbGaP. Nucleic Acids Res 2013:

56. Fung HC, Scholz S, Matarin M, Simon-Sanchez J, Hernandez D, Britton A, Gibbs JR, Langefeld C, Stiegert ML, Schymick J, Okun MS, Mandel RJ, Fernandez $\mathrm{HH}$, Foote KD, Rodríguez RL, Peckham E, De Vrieze FW Gwinn-Hardy K, Hardy JA, Singleton A: Genome-wide genotyping in Parkinson's disease and neurologically normal controls: first stage analysis and public release of data. Lancet Neurol 2006, 5(11):911-916.

57. Simon-Sanchez J, Scholz S, Fung HC, Matarin M, Hernandez D, Gibbs JR, Britton A, de Vrieze FW, Peckham E, Gwinn-Hardy K, Crawley A, Keen JC, Nash J, Borgaonkar D, Hardy J, Singleton A: Genome-wide SNP assay reveals structural genomic variation, extended homozygosity and cell-line induced alterations in normal individuals. Hum Mol Genet 2007, 16(1):1-14.

58. Simon-Sanchez J, Schulte C, Bras JM, Sharma M, Gibbs JR, Berg D, Paisan-Ruiz C, Lichtner P, Scholz SW, Hernandez DG, Krüger R, Federoff M, Klein C, Goate A, Perlmutter J, Bonin M, Nalls MA, Illig T, Gieger C, Houlden H, Steffens M, Okun MS, Racette BA, Cookson MR, Foote KD, Fernandez HH, Traynor BJ, Schreiber S, Arepalli S, Zonozi R, et al: Genome-wide association study reveals genetic risk underlying Parkinson's disease. Nat Genet 2009, 41(12):1308-1312.

59. Zhang Y, James M, Middleton FA, Davis RL: Transcriptional analysis of multiple brain regions in Parkinson's disease supports the involvement of specific protein processing, energy metabolism, and signaling pathways, and suggests novel disease mechanisms. Am J Med Genet B Neuropsychiatr Genet 2005, 137B(1):5-16.

60. Bras J, Guerreiro R, Hardy J: Use of next-generation sequencing and other whole-genome strategies to dissect neurological disease. Nat Rev Neurosci 2012, 13(7):453-464.

61. Smith AV: Genetic analysis: moving between linkage and association. Cold Spring Harb Protoc 2012, 2012(2):174-182.

62. Dorval V, Smith PY, Delay C, Calvo E, Planel E, Zommer N, Buee L, Hebert SS: Gene network and pathway analysis of mice with conditional ablation of Dicer in post-mitotic neurons. PLoS One 2012, 7(8):e44060.

63. Hudson NJ, Dalrymple BP, Reverter A: Beyond differential expression: the quest for causal mutations and effector molecules. BMC Genomics 2012, 13:356.

64. Boehnke M: Limits of resolution of genetic linkage studies: implications for the positional cloning of human disease genes. Am J Hum Genet 1994, 55(2):379-390

65. Ge X, Loh HH, Law PY: mu-Opioid receptor cell surface expression is regulated by its direct interaction with Ribophorin I. Mol Pharmacol 2009, 75(6):1307-1316.

66. Mathieu-Kia AM, Fan LQ, Kreek MJ, Simon EJ, Hiller JM: Mu-, delta- and kappa-opioid receptor populations are differentially altered in distinct areas of postmortem brains of Alzheimer's disease patients. Brain Res 2001, 893(1-2):121-134.

67. Teng L, Zhao J, Wang F, Ma L, Pei G: A GPCR/secretase complex regulates beta- and gamma-secretase specificity for Abeta production and contributes to AD pathogenesis. Cell Res 2010, 20(2):138-153.

68. Saetre $P$, Jazin E, Emilsson L: Age-related changes in gene expression are accelerated in Alzheimer's disease. Synapse 2011, 65(9):971-974.
69. Muma NA, Mariyappa R, Williams K, Lee JM: Differences in regional and subcellular localization of $\mathrm{G}(\mathrm{q} / 11)$ and RGS4 protein levels in Alzheimer's disease: correlation with muscarinic M1 receptor binding parameters. Synapse 2003, 47(1):58-65.

70. Bradley SV, Holland EC, Liu GY, Thomas D, Hyun TS, Ross TS: Huntingtin interacting protein 1 is a novel brain tumor marker that associates with epidermal growth factor receptor. Cancer Res 2007, 67(8):3609-3615.

71. Walter S, Atzmon G, Demerath EW, Garcia ME, Kaplan RC, Kumari M, Lunetta KL, Milaneschi Y, Tanaka T, Tranah GJ, Völker U, Yu L, Arnold A, Benjamin EJ, Biffar R, Buchman AS, Boerwinkle E, Couper D, De Jager PL, Evans DA, Harris TB, Hoffmann W, Hofman A, Karasik D, Kiel DP, Kocher T, Kuningas M, Launer LJ, Lohman KK, Lutsey PL, et al: A genome-wide association study of aging. Neurobiol Aging 2011, 32(11):2109. e15-28.

72. Mills IG, Gaughan L, Robson C, Ross T, McCracken S, Kelly J, Neal DE: Huntingtin interacting protein 1 modulates the transcriptional activity of nuclear hormone receptors. J Cell Biol 2005, 170(2):191-200.

73. Menegon A, Burgaya F, Baudot P, Dunlap DD, Girault JA, Valtorta F: FAK + and PYK2/CAKbeta, two related tyrosine kinases highly expressed in the central nervous system: similarities and differences in the expression pattern. Eur J Neurosci 1999, 11(11):3777-3788.

74. Combs CK, Johnson DE, Cannady SB, Lehman TM, Landreth GE: Identification of microglial signal transduction pathways mediating a neurotoxic response to amyloidogenic fragments of beta-amyloid and prion proteins. J Neurosci 1999, 19(3):928-939.

75. Huang Y, Lu W, Ali DW, Pelkey KA, Pitcher GM, Lu YM, Aoto H, Roder JC, Sasaki T, Salter MW, MacDonald JF: CAKbeta/Pyk2 kinase is a signaling link for induction of long-term potentiation in CA1 hippocampus. Neuron 2001, 29(2):485-496.

76. Park SY, Avraham H, Avraham S: Characterization of the tyrosine kinases RAFTK/Pyk2 and FAK in nerve growth factor-induced neuronal differentiation. J Biol Chem 2000, 275(26):19768-19777.

77. Siciliano JC, Toutant M, Derkinderen P, Sasaki T, Girault JA: Differential regulation of proline-rich tyrosine kinase 2 /cell adhesion kinase beta (PYK2/CAKbeta) and pp 125(FAK) by glutamate and depolarization in rat hippocampus. J Biol Chem 1996, 271(46):28942-28946.

78. Cotman CW, Anderson AJ: A potential role for apoptosis in neurodegeneration and Alzheimer's disease. Mol Neurobiol 1995, 10(1):19-45.

79. Tian D, Litvak V, Lev S: Cerebral ischemia and seizures induce tyrosine phosphorylation of PYK2 in neurons and microglial cells. J Neurosci 2000, 20(17):6478-6487.

80. Pilon M, Peng XR, Spence AM, Plasterk RH, Dosch HM: The diabetes autoantigen ICA69 and its Caenorhabditis elegans homologue, ric-19, are conserved regulators of neuroendocrine secretion. Mol Biol Cell 2000 11(10):3277-3288.

81. Cao M, Xu J, Shen C, Kam C, Huganir RL, Xia J: PICK1-ICA69 heteromeric BAR domain complex regulates synaptic targeting and surface expression of AMPA receptors. J Neurosci 2007, 27(47):12945-12956.

82. Spitzenberger F, Pietropaolo S, Verkade P, Habermann B, Lacas-Gervais S, Mziaut H, Pietropaolo M, Solimena M: Islet cell autoantigen of $69 \mathrm{kDa}$ is an arfaptin-related protein associated with the Golgi complex of insulinoma INS-1 cells. J Biol Chem 2003, 278(28):26166-26173.

83. Wu Y, Matsui H, Tomizawa K: Amphiphysin I and regulation of synaptic vesicle endocytosis. Acta Med Okayama 2009, 63(6):305-323.

84. Di Paolo G, Sankaranarayanan S, Wenk MR, Daniell L, Perucco E, Caldarone BJ, Flavell R, Picciotto MR, Ryan TA, Cremona O, De Camilli P: Decreased synaptic vesicle recycling efficiency and cognitive deficits in amphiphysin 1 knockout mice. Neuron 2002, 33(5):789-804.

85. De Jesus-Cortes HJ, Nogueras-Ortiz CJ, Gearing M, Arnold SE, Vega IE: Amphiphysin-1 protein level changes associated with tau-mediated neurodegeneration. Neuroreport 2012, 23(16):942-946.

86. Kelly BL, Ferreira A: Beta-amyloid disrupted synaptic vesicle endocytosis in cultured hippocampal neurons. Neuroscience 2007, 147(1):60-70.

87. Wang L, Chiang HC, Wu W, Liang B, Xie Z, Yao X, Ma W, Du S, Zhong Y: Epidermal growth factor receptor is a preferred target for treating amyloid-beta-induced memory loss. Proc Natl Acad Sci U S A 2012, 109(41):16743-16748.

88. Zhang YW, Wang R, Liu Q, Zhang H, Liao FF, Xu H: Presenilin/gammasecretase-dependent processing of beta-amyloid precursor protein regulates EGF receptor expression. Proc Natl Acad Sci U S A 2007, 104(25):10613-10618. 
89. Repetto $E$, Yoon IS, Zheng $H$, Kang DE: Presenilin 1 regulates epidermal growth factor receptor turnover and signaling in the endosomallysosomal pathway. J Biol Chem 2007, 282(43):31504-31516.

90. Conejero-Goldberg C, Hyde TM, Chen S, Dreses-Werringloer U, Herman MM, Kleinman JE, Davies P, Goldberg TE: Molecular signatures in post-mortem brain tissue of younger individuals at high risk for Alzheimer's disease as based on APOE genotype. Mol Psychiatry 2011, 16(8):836-847.

91. Akram A, Schmeidler J, Katsel P, Hof PR, Haroutunian V: Increased expression of cholesterol transporter $A B C A 1$ is highly correlated with severity of dementia in AD hippocampus. Brain Res 2010, 1318:167-177.

92. Elali $A$, Rivest $S$ : The role of $A B C B 1$ and $A B C A 1$ in beta-amyloid clearance at the neurovascular unit in Alzheimer's disease. Front Physiol 2013, 4:45.

93. Wildsmith KR, Holley M, Savage JC, Skerrett R, Landreth GE: Evidence for impaired amyloid beta clearance in Alzheimer's disease. Alzheimers Res Ther 2013, 5(4):33.

94. Wahrle SE, Jiang H, Parsadanian M, Kim J, Li A, Knoten A, Jain S, HirschReinshagen V, Wellington CL, Bales KR, Paul SM, Holtzman DM: Overexpression of ABCA1 reduces amyloid deposition in the PDAPP mouse model of Alzheimer disease. J Clin Invest 2008, 118(2):671-682.

95. Fitz NF, Cronican AA, Saleem M, Fauq AH, Chapman R, Lefterov I, Koldamova R: Abca1 deficiency affects Alzheimer's disease-like phenotype in human ApoE4 but not in ApoE3-targeted replacement mice. J Neurosci 2012, 32(38):13125-13136.

96. Malik B, Fernandes C, Killick R, Wroe R, Usardi A, Williamson R, Kellie S, Anderton $\mathrm{BH}$, Reynolds $\mathrm{CH}$ : Oligomeric amyloid-beta peptide affects the expression of genes involved in steroid and lipid metabolism in primary neurons. Neurochem Int 2012, 61(3):321-333.

97. Canepa E, Borghi R, Vina J, Traverso N, Gambini J, Domenicotti C, Marinari UM, Poli G, Pronzato MA, Ricciarelli R: Cholesterol and amyloid-beta: evidence for a cross-talk between astrocytes and neuronal cells. J Alzheimers Dis 2011, 25(4):645-653.

98. Donkin JJ, Stukas S, Hirsch-Reinshagen V, Namjoshi D, Wilkinson A, May S, Chan J, Fan J, Collins J, Wellington CL: ATP-binding cassette transporter A1 mediates the beneficial effects of the liver X receptor agonist GW3965 on object recognition memory and amyloid burden in amyloid precursor protein/presenilin 1 mice. J Biol Chem 2010, 285(44):34144-34154.

99. Fan J, Donkin J, Wellington C: Greasing the wheels of Abeta clearance in Alzheimer's disease: the role of lipids and apolipoprotein E. Biofactors 2009, 35(3):239-248

100. Koldamova R, Fitz NF, Lefterov I: The role of ATP-binding cassette transporter A1 in Alzheimer's disease and neurodegeneration. Biochim Biophys Acta 2010, 1801(8):824-830.

101. Wang XF, Cao YW, Feng ZZ, Fu D, Ma YS, Zhang F, Jiang XX, Shao YC: Quantitative assessment of the effect of $A B C A 1$ gene polymorphism on the risk of Alzheimer's disease. Mol Biol Rep 2013, 40(2):779-785.

102. Lupton MK, Proitsi P, Lin K, Hamilton G, Daniilidou M, Tsolaki M, Powell JF: The Role of ABCA1 Gene Sequence Variants on Risk of Alzheimer's Disease. J Alzheimers Dis 2014, 38(4):897-906.

103. Butterfield DA, Castegna A, Lauderback CM, Drake J: Evidence that amyloid beta-peptide-induced lipid peroxidation and its sequelae in Alzheimer's disease brain contribute to neuronal death. Neurobiol Aging 2002 23(5):655-664

104. Ricciarelli R, d'Abramo C, Massone S, Marinari U, Pronzato M, Tabaton M: Microarray analysis in Alzheimer's disease and normal aging. IUBMB Life 2004, 56(6):349-354

105. Leduc $V$, Legault $V$, Dea D, Poirier J: Normalization of gene expression using SYBR green qPCR: a case for paraoxonase 1 and 2 in Alzheimer's disease brains. J Neurosci Methods 2011, 200(1):14-19.

106. Maloney MT, Minamide LS, Kinley AW, Boyle JA, Bamburg JR: Betasecretase-cleaved amyloid precursor protein accumulates at actin inclusions induced in neurons by stress or amyloid beta: a feedforward mechanism for Alzheimer's disease. J Neurosci 2005, 25(49):11313-11321.

107. Bamburg JR, Bloom GS: Cytoskeletal pathologies of Alzheimer disease. Cell Motil Cytoskeleton 2009, 66(8):635-649.

108. Yao J, Khan AN: Involvement of Actin Pathology in Alzheimer's disease. Cell Dev Biol 2013, 2:e121. doi:10.4172/2168-9296.1000e121.

109. Tell V, Holzer M, Herrmann L, Mahmoud KA, Schächtele C, Totzke F, Hilgeroth A: Multitargeted drug development: Discovery and profiling of dihydroxy substituted 1-aza-9-oxafluorenes as lead compounds targeting Alzheimer disease relevant kinases. Bioorg Med Chem Lett 2012, 22(22):6914-8
110. Chang KH, Vincent F, Shah K: Deregulated Cdk5 triggers aberrant activation of cell cycle kinases and phosphatases inducing neuronal death. J Cell Sci 2012, 125(Pt 21):5124-5137.

111. Cui JG, Li YY, Zhao Y, Bhattacharjee S, Lukiw WJ: Differential regulation of interleukin-1 receptor-associated kinase-1 (IRAK-1) and IRAK-2 by microRNA-146a and NF-kappaB in stressed human astroglial cells and in Alzheimer disease. J Biol Chem 2010, 285(50):38951-38960.

112. Hu WT, Holtzman DM, Fagan AM, Shaw LM, Perrin R, Arnold SE, Grossman M, Xiong C, Craig-Schapiro R, Clark CM Pickering E, Kuhn M, Chen Y, Van Deerlin VM, McCluskey L, Elman L, Karlawish J, Chen-Plotkin A, Hurtig HI, Siderowf A, Swenson F, Lee VM, Morris JC, Trojanowski JQ, Soares H, Alzheimer's Disease Neuroimaging Initiative: Plasma multianalyte profiling in mild cognitive impairment and Alzheimer disease. Neurology 2012, 79(9):897-905

113. Song F, Poljak A, Crawford J, Kochan NA, Wen W, Cameron B, Lux O, Brodaty H, Mather K, Smythe GA, Sachdev PS: Plasma apolipoprotein levels are associated with cognitive status and decline in a community cohort of older individuals. PLOS One 2012, 7(6):e34078

114. Vuletic S, Li G, Peskind ER, Kennedy H, Marcovina SM, Leverenz JB, Petrie EC, Lee VM, Galasko D, Schellenberg GD, Albers JJ: Apolipoprotein E highly correlates with AbetaPP- and tau-related markers in human cerebrospinal fluid. J Alzheimers Dis 2008, 15(3):409-417.

115. Fukuyama R, Mizuno T, Mori S, Yanagisawa K, Nakajima K, Fushiki S: Age-dependent decline in the apolipoprotein E level in cerebrospinal fluid from control subjects and its increase in cerebrospinal fluid from patients with Alzheimer's disease. Eur Neurol 2000, 43(3):161-169.

116. Hesse C, Larsson H, Fredman P, Minthon L, Andreasen N, Davidsson P, Blennow K: Measurement of apolipoprotein $E$ (apoE) in cerebrospinal fluid. Neurochem Res 2000, 25(4):511-517.

117. Cruchaga C, Kauwe JS, Nowotny P, Bales K, Pickering EH, Mayo K, Bertelsen S, Hinrichs A, Fagan AM, Holtzman DM Morris JC, Goate AM: Cerebrospinal fluid APOE levels: an endophenotype for genetic studies for Alzheimer's disease. Hum Mol Genet 2012, 21(20):4558-4571.

118. Skoog I, Hesse C, Fredman P, Andreasson LA, Palmertz B, Blennow K: Apolipoprotein $\mathrm{E}$ in cerebrospinal fluid in 85-year-old subjects. Relation to dementia, apolipoprotein E polymorphism, cerebral atrophy, and white matter lesions. Arch Neurol 1997, 54(3):267-272.

119. Merched A, Blain H, Visvikis S, Herbeth B, Jeandel C, Siest G: Cerebrospinal fluid apolipoprotein E level is increased in late-onset Alzheimer's disease. J Neurol Sci 1997, 145(1):33-39.

120. Lindh M, Blomberg M, Jensen M, Basun H, Lannfelt L, Engvall B, Scharnagel $\mathrm{H}$, Marz W, Wahlund LO, Cowburn RF: Cerebrospinal fluid apolipoprotein E (apoE) levels in Alzheimer's disease patients are increased at follow up and show a correlation with levels of tau protein. Neurosci Lett 1997 229(2):85-88.

121. Doecke JD, Laws SM, Faux NG, Wilson W, Burnham SC, Lam CP, Mondal A, Bedo J, Bush Al, Brown B, De Ruyck K, Ellis KA, Fowler C, Gupta VB, Head R, Macaulay SL, Pertile K, Rowe CC, Rembach A, Rodrigues M, Rumble R, Szoeke C, Taddei K, Taddei T, Trounson B, Ames D, Masters CL, Martins RN, Alzheimer's Disease Neuroimaging Initiative; Australian Imaging Biomarker and Lifestyle Research Group: Blood-based protein biomarkers for diagnosis of Alzheimer disease. Arch Neurol 2012, 69(10):1318-1325.

122. Moskvina V, Harold D, Russo G, Vedernikov A, Sharma M, Saad M, Holmans P, Bras JM, Bettella F, Keller MF, Nicolaou N, Simón-Sánchez J, Gibbs JR, Schulte C, Durr A, Guerreiro R, Hernandez D, Brice A, Stefánsson H, Majamaa K, Gasser T, Heutink P, Wood N, Martinez M, Singleton AB, Nalls MA, Hardy J, Owen MJ, O'Donovan MC, Williams J, et al: Analysis of Genome-Wide Association Studies of Alzheimer Disease and of Parkinson Disease to Determine If These 2 Diseases Share a Common Genetic Risk. JAMA Neurol 2013, 70(10):1268-76.

123. Marder K, Tang MX, Alfaro B, Mejia H, Cote L, Louis E, Stern Y, Mayeux R: Risk of Alzheimer's disease in relatives of Parkinson's disease patients with and without dementia. Neurology 1999, 52(4):719-724.

124. Levy G, Louis ED, Mejia-Santana H, Cote L, Andrews H, Harris J, Waters C, Ford B, Frucht S, Fahn S, Ottman R, Marder K: Lack of familial aggregation of Parkinson disease and Alzheimer disease. Arch Neurol 2004 61(7):1033-1039.

125. Rocca WA, Bower JH, Ahlskog JE, Elbaz A, Grossardt BR, McDonnell SK, Schaid DJ, Maraganore DM: Risk of cognitive impairment or dementia in relatives of patients with Parkinson disease. Arch Neurol 2007, 64(10):1458-1464. 
126. Hart GT, Ramani AK, Marcotte EM: How complete are current yeast and human protein-interaction networks? Genome Biol 2006, 7(11):120.

127. Moreau Y, Tranchevent LC: Computational tools for prioritizing candidate genes: boosting disease gene discovery. Nat Rev Genet 2012, 13(8):523-536.

128. Bornigen D, Tranchevent LC, Bonachela-Capdevila F, Devriendt K, De Moor $B$, De Causmaecker P, Moreau Y: An unbiased evaluation of gene prioritization tools. Bioinformatics 2012, 28(23):3081-3088.

129. Antunez C, Boada M, Gonzalez-Perez A, Gayan J, Ramirez-Lorca R, Marin J, Hernandez I, Moreno-Rey C, Moron FJ, Lopez-Arrieta J, Mauleón A, Rosende-Roca M, Noguera-Perea F, Legaz-García A, Vivancos-Moreau L, Velasco J, Carrasco JM, Alegret M, Antequera-Torres M, Manzanares S, Romo A, Blanca I, Ruiz S, Espinosa A, Castaño S, García B, Martínez-Herrada B, Vinyes G, Lafuente A, Becker JT, et al: The membrane-spanning 4-domains, subfamily A (MS4A) gene cluster contains a common variant associated with Alzheimer's disease. Genome Med 2011, 3(5):33.

130. Reiman EM, Webster JA, Myers AJ, Hardy J, Dunckley T, Zismann VL, Joshipura KD, Pearson JV, Hu-Lince D, Huentelman MJ, Craig DW, Coon KD, Liang WS, Herbert RH, Beach T, Rohrer KC, Zhao AS, Leung D, Bryden L, Marlowe L, Kaleem M, Mastroeni D, Grover A, Heward CB, Ravid R, Rogers J, Hutton ML, Melquist S, Petersen RC, Alexander GE, et al: GAB2 alleles modify Alzheimer's risk in APOE epsilon4 carriers. Neuron 2007, 54(5):713-720.

131. Mueller SG, Weiner MW, Thal $\amalg$, Petersen RC, Jack CR, Jagust W, Trojanowski JQ, Toga AW, Beckett L: Ways toward an early diagnosis in Alzheimer's disease: the Alzheimer's Disease Neuroimaging Initiative (ADNI). Alzheimers Dement 2005, 1(1):55-66

132. Li H, Wetten S, Li L, St Jean PL, Upmanyu R, Surh L, Hosford D, Barnes MR, Briley JD, Borrie M, Coletta N, Delisle R, Dhalla D, Ehm MG, Feldman HH, Fornazzari L, Gauthier S, Goodgame N, Guzman D, Hammond S, Hollingworth P, Hsiung GY, Johnson J, Kelly DD, Keren R, Kertesz A, King KS, Lovestone S, Loy-English I, Matthews PM, et al: Candidate singlenucleotide polymorphisms from a genomewide association study of Alzheimer disease. Arch Neurol 2008, 65(1):45-53.

133. Wijsman EM, Pankratz ND, Choi Y, Rothstein JH, Faber KM, Cheng R, Lee JH, Bird TD, Bennett DA, Diaz-Arrastia R, Goate AM, Farlow M, Ghetti B, Sweet RA, Foroud TM, Mayeux R, NIA-LOAD/NCRAD Family Study Group: Genome-wide association of familial late-onset Alzheimer's disease replicates BIN1 and CLU and nominates CUGBP2 in interaction with APOE. PLOS Genet 2011, 7(2):e1001308.

134. Hu X, Pickering E, Liu YC, Hall S, Fournier H, Katz E, Dechairo B, John S, Van Eerdewegh $\mathrm{P}$, Soares $\mathrm{H}$, Alzheimer's Disease Neuroimaging Initiative: Meta-analysis for genome-wide association study identifies multiple variants at the BIN1 locus associated with late-onset Alzheimer's disease. PLoS One 2011, 6(2):e16616.

135. Harold D, Abraham R, Hollingworth P, Sims R, Gerrish A, Hamshere ML, Pahwa JS, Moskvina V, Dowzell K, Williams A, Jones N, Thomas C, Stretton A, Morgan AR, Lovestone S, Powell J, Proitsi P, Lupton MK, Brayne C, Rubinsztein DC, Gill M, Lawlor B, Lynch A, Morgan K, Brown KS, Passmore PA, Craig D, McGuinness B, Todd S, Holmes C, et al: Genome-wide association study identifies variants at CLU and PICALM associated with Alzheimer's disease. Nat Genet 2009, 41(10):1088-1093.

136. Ramensky $V$, Bork P, Sunyaev S: Human non-synonymous SNPs: server and survey. Nucleic Acids Res 2002, 30(17):3894-3900

137. Adzhubei IA, Schmidt S, Peshkin L, Ramensky VE, Gerasimova A, Bork P, Kondrashov AS, Sunyaev SR: A method and server for predicting damaging missense mutations. Nat Methods 2010, 7(4):248-249.

138. Loots G, Ovcharenko I: ECRbase: database of evolutionary conserved regions, promoters, and transcription factor binding sites in vertebrate genomes. Bioinformatics 2007, 23(1):122-124.

139. International HapMap Consortium, Frazer KA, Ballinger DG, Cox DR, Hinds DA, Stuve LL, Gibbs RA, Belmont JW, Boudreau A, Hardenbol P, Leal SM, Pasternak S, Wheeler DA, Willis TD, Yu F, Yang H, Zeng C, Gao Y, Hu H, Hu W, Li C, Lin W, Liu S, Pan H, Tang X, Wang J, Wang W, Yu J, Zhang B, Zhang $Q$, et al: A second generation human haplotype map of over 3.1 million SNPs. Nature 2007, 449(7164):851-861.

140. Gray KA, Daugherty LC, Gordon SM, Seal RL, Wright MW, Bruford EA: Genenames.org: the HGNC resources in 2013. Nucleic Acids Res 2013 41(Database issue):D545-552

141. Silla $Y$, Sundaramoorthy $E$, Talwar $P$, Sengupta S: S-linked protein homocysteinylation: identifying targets based on structural, physicochemical and protein-protein interactions of homocysteinylated proteins. Amino Acids 2013, 44(5):1307-1316.

142. Wu CH, Apweiler R, Bairoch A, Natale DA, Barker WC, Boeckmann B, Ferro S, Gasteiger E, Huang H, Lopez R, Magrane M, Martin MJ, Mazumder R, O'Donovan C, Redaschi N, Suzek B: The Universal Protein Resource (UniProt): an expanding universe of protein information. Nucleic Acids Res 2006, 34(Database issue):D187-191.

143. Assenov Y, Ramirez F, Schelhorn SE, Lengauer T, Albrecht M: Computing topological parameters of biological networks. Bioinformatics 2008 24(2):282-284.

144. Uhlen M, Oksvold P, Fagerberg L, Lundberg E, Jonasson K, Forsberg M, Zwahlen M, Kampf C, Wester K, Hober S, Wernerus H, Björling L, Ponten F: Towards a knowledge-based Human Protein Atlas. Nat Biotechnol 2010, 28(12):1248-1250.

145. Brohee $S$, van Helden J: Evaluation of clustering algorithms for proteinprotein interaction networks. BMC Bioinformatics 2006, 7:488.

146. Li SJ, Peng M, Li H, Liu BS, Wang C, Wu JR, Li YX, Zeng R: Sys-BodyFluid: a systematical database for human body fluid proteome research. Nucleic Acids Res 2009, 37(Database issue):D907-912.

147. Pirooznia M, Nagarajan V, Deng Y: GeneVenn - A web application for comparing gene lists using Venn diagrams. Bioinformation 2007, 1(10):420-422.

doi:10.1186/1471-2164-15-199

Cite this article as: Talwar et al:: Genomic convergence and network analysis approach to identify candidate genes in Alzheimer's disease. BMC Genomics 2014 15:199.

\section{Submit your next manuscript to BioMed Central and take full advantage of:}

- Convenient online submission

- Thorough peer review

- No space constraints or color figure charges

- Immediate publication on acceptance

- Inclusion in PubMed, CAS, Scopus and Google Scholar

- Research which is freely available for redistribution 